\title{
Monocytes as Endothelial Progenitor Cells (EPCs), Another Brick in the Wall to Disentangle Tumor Angiogenesis
}

\author{
Filipa Lopes-Coelho ${ }^{1,2}$, Fernanda Silva ${ }^{1,2}$, Sofia Gouveia-Fernandes ${ }^{1,2}$, Carmo Martins ${ }^{2}$, \\ Nuno Lopes ${ }^{3}$, Germana Domingues ${ }^{1,2}$, Catarina Brito ${ }^{3,4} \mathbb{D}$, António M Almeida ${ }^{2,5}$, \\ Sofia A Pereira ${ }^{1}$ and Jacinta Serpa ${ }^{1,2, *(\mathbb{D})}$ \\ 1 CEDOC, Chronic Diseases Research Centre, NOVA Medical School|Faculdade de Ciências Médicas, \\ Universidade NOVA de Lisboa, Campo dos Mártires da Pátria, 130, 1169-056 Lisboa, Portugal; \\ filipa.coelho@nms.unl.pt (F.L.-C.); fernanda.silva@nms.unl.pt (F.S.); sofia.gopf@live.com.pt (S.G.-F.); \\ germana.andreia@gmail.com (G.D.); sofia.pereira@nms.unl.pt (S.A.P.) \\ 2 Instituto Português de Oncologia de Lisboa Francisco Gentil (IPOLFG), Rua Prof. Lima Basto 1099-023 \\ Lisboa, Portugal; mcmartins@ipolisboa.min-saude.pt (C.M.); amalmeida1@gmail.com (A.M.A.) \\ 3 Instituto de Biologia Experimental e Tecnológica, Avenida da República, Estação Agronómica, \\ 2780-157 Oeiras, Portugal; nlopes@ibet.pt (N.L.); anabrito@ibet.pt (C.B.) \\ 4 Instituto de Tecnologia Química e Biológica António Xavier, Universidade Nova de Lisboa, Av. da República, \\ 2780-157 Oeiras, Portugal \\ 5 Hospital da Luz, Av. Lusíada 100, 1500-650 Lisboa, Portugal \\ * Correspondence: jacinta.serpa@nms.unl.pt; Tel.: +350-217-229-800; Fax: +351-217-248-756
}

Received: 4 November 2019; Accepted: 30 December 2019; Published: 1 January 2020

\begin{abstract}
Bone marrow contains endothelial progenitor cells (EPCs) that, upon pro-angiogenic stimuli, migrate and differentiate into endothelial cells (ECs) and contribute to re-endothelialization and neo-vascularization. There are currently no reliable markers to characterize EPCs, leading to their inaccurate identification. In the past, we showed that, in a panel of tumors, some cells on the vessel wall co-expressed CD14 (monocytic marker) and CD31 (EC marker), indicating a putative differentiation route of monocytes into ECs. Herein, we disclosed monocytes as potential EPCs, using in vitro and in vivo models, and also addressed the cancer context. Monocytes acquired the capacity to express ECs markers and were able to be incorporated into blood vessels, contributing to cancer progression, by being incorporated in tumor neo-vasculature. Reactive oxygen species (ROS) push monocytes to EC differentiation, and this phenotype is reverted by cysteine (a scavenger and precursor of glutathione), which indicates that angiogenesis is controlled by the interplay between the oxidative stress and the scavenging capacity of the tumor microenvironment.
\end{abstract}

Keywords: monocytes; endothelial progenitor cells (EPCs); endothelial cells (ECs); angiogenesis; cancer

\section{Introduction}

Tumor angiogenesis is essential to provide oxygen and nutrients to cancer cells, and to remove waste products from the tumor microenvironment. Therefore, neovascularization has a crucial role during carcinogenesis, by promoting tumor growth and invasion and ultimately leading to metastasis [1,2]. Over the last two decades, cancer treatment using anti-angiogenic therapies has fallen short of expectations [3], showing that the mechanisms underlying neovascularization in cancer are not fully understood. This failure can be explained, at least in part, by the fact that the specific origin of endothelial progenitor cells (EPCs) is not yet determined. 
Over the last decade, different studies reported EPCs as essential in restoring injured vessels. EPCs belong to a subset of cells, arising from hematopoietic stem cells in bone marrow; upon pro-angiogenic stimuli, they proliferate, migrate, and differentiate into endothelial cells (ECs) [4-6]. Some reports addressing EPCs and disease, such as systemic sclerosis, showed contradictory and discrepant results about EPCs mobilization and differentiation; in part, because there is a lack of a precise panel of cell surface markers used for the characterization of this subset of cells [4-10]. In mouse embryonic vascular endothelium, erythro-myeloid progenitors (EMPs) can differentiate into ECs [11] and in a mouse model of carotid injury, monocytes (CD14 ${ }^{+}$cells) are capable of improving re-endothelialization [12]. In vivo and in vitro targeting of Tie2-monocytes decreases angiogenesis by abrogating EC proliferation [13-15] and an in vivo CCR2 (chemokine (C-C motif) receptor 2) knockout impairs monocytes recruitment and VEGFA (also named VEGF, vascular endothelial growth factor) expression, accompanied by a reduction in the angiogenesis rate [16]. The release of cytokines and pro-angiogenic factors (e.g., VEGFA, VEGFC, and VEGFD, TNF $\alpha$ (tumor necrosis factor $\alpha$ ), IL-8 (interleukin-8), and FGF-2 (fibroblast growth factor-2), and extracellular matrix (ECM) modifying proteins (e.g., metalloproteinase-9 (MMP-9)) by macrophages enhances the tissue's ability to support capillary sprouting and vascular density $[17,18]$. The precise mechanism by which monocytes influence angiogenesis in tissue development, homeostasis, and diseases is not fully understood. However, different studies, have shown that under in vitro pro-angiogenic pressure, blood mononuclear cells can acquire endothelial markers and morphology [19-21]. In addition, in a previous study, we showed that some ECs simultaneously expressed CD14 (monocytic marker) and CD31 (EC marker), indicating mixed features between monocytes and ECs, in tumors and normal tissues [22]. We truly believe that monocytes are promising candidates for EPCs.

Reactive oxygen species (ROS) are reported as essential for the maintenance of endothelium homeostasis by acting as physiological regulators of intracellular signaling, whilst a redox imbalance can prompt vascular diseases [23-28]. Nevertheless, some contradiction persists amongst biological models. In a rat model, hydrogen peroxide $\left(\mathrm{H}_{2} \mathrm{O}_{2}\right)$ inhibits the differentiation of rat multipotent adult progenitor cells (MAPCs), including bone marrow stem cells and EPCs [29-31], whereas it enhances the rate of cell differentiation of human embryonic stem cells [32]. Based on these contradictory observations, we believe the effects of ROS will depend on the cell lineage and its differentiation level.

Herein, we propose to prove, in vitro and in vivo, that monocytes can act as EPCs, being able to incorporate in the neo-vasculature and favor cancer development. Moreover, we used $\mathrm{H}_{2} \mathrm{O}_{2}$ (ROS) as a stimulus to trigger monocyte-EC differentiation.

\section{Materials and Methods}

\subsection{Monocytes Isolation and Culture}

Monocytes were isolated from peripheral blood, collected under consenting donation of healthy donors from Serviço de Imuno-Hemoterapia at Instituto Português de Oncologia de Lisboa Francisco Gentil (IPOLFG) (IPOLFG-Ethical committee UIC-1137). Peripheral blood mononuclear cells (PBMCs) from blood samples were separated using Histopaque-1077 (10771, Sigma-Aldrich, Saint Louis, MO, USA), followed by magnetic monocytes isolation using a Monocyte isolation kit II (130-091-153, MACS Technology-MiltenyiBiotec, Bergisch Gladbach, Germany), according to the manufacturers' protocols. Monocytes were cultured in plates coated with $0.2 \%$ gelatine (G-1890, Sigma-Aldrich) or with Matrigel (354230, Corning, NY, USA) and maintained in Colony-Forming Unit (CFU) medium (130-091-277, MACS Technology-MiltenyiBiotec) or Endothelial-Basal Medium-2(EBM-2) (CC-3156, Lonza, Basel, Swiss) plus Endothelial-cell Growth Medium (EGM ${ }^{\mathrm{TM}_{-}}$) bullet kit SingleQuotsTM Supplements (CC-4176, Lonza) and with 2\% fetal bovine serum (FBS; CC4101A, Lonza), $50 \mathrm{ng} / \mathrm{mL}$ vascular endothelial growth factor (VEGF; V7259, Sigma-Aldrich) and $10 \mathrm{U} / \mathrm{mL}$ heparin (H3149, Sigma-Aldrich). Cells were maintained at $37^{\circ} \mathrm{C}$, in a humidified atmosphere and $0.5 \% \mathrm{CO}_{2}$. Hydrogen peroxide, $(15 \mu \mathrm{M}$; $\mathrm{H}_{2} \mathrm{O}_{2} ; 1.07210 .0250$, Merck, Saint Louis, MO, USA) was used as a ROS generator, cysteine (0.4 mM; 
Cys; 7048-04-6, Merck) was used as an anti-oxidant, and disulfiram was used as an ALDH (aldehyde dehydrogenase) inhibitor ( $2 \mu \mathrm{M} ; 86720$, Fluka, Munich, Germany).

\subsection{Cell Culture}

Human umbilical vein endothelial cells (HUVEC; ATCC ${ }^{\circledR}$ CRL-1730 ${ }^{\mathrm{TM}}$ ) were seeded in plates coated with $0.2 \%$ gelatine and cultured in EBM-2 (CC-3156, Lonza) plus EGMTM-2 SingleQuotsTM Supplements (CC-4176, Lonza) medium supplemented with 2\% FBS.

Breast cancer cells (MDA-MB-231; ATCC ${ }^{\circledR}$ HTB-26 ${ }^{\mathrm{TM}}$, and HCC1954; ATCC ${ }^{\circledR}$ CRL 2338 ${ }^{\mathrm{TM}}$ ) were cultured in DMEM - Dulbecco's Modified Eagle Medium (DMEM) (11965-092, Gibco-Thermo Fisher Scientific, Waltham, MA, USA) supplemented with 10\% FBS and 1\% Antibiotic-Antimycotic (15240062, Invitrogen ${ }^{\mathrm{TM}}$-Thermo Fisher Scientific) and Roswell Park Memorial Institute (RPMI)- 1640, no phenol red (\#11835-063, Invitrogen, Waltham, MA, USA) supplemented with 10\% FBS, 1\% Penicillin and streptavidin (15140-163, Gibco-Thermo Fisher Scientific), $0.5 \mathrm{~mL}$ 2- $\beta$-Mercaptoetanol (21985-023, Gibco-Thermo Fisher Scientific) and $3 \mathrm{~mL}$ HEPES (4-(2-hydroxyethyl)-1-piperazineethanesulfonic acid; 15630-056, Gibco-Thermo Fisher Scientific) (respectively). Cells were maintained at $37^{\circ} \mathrm{C}$, in a humidified atmosphere and $5 \% \mathrm{CO}_{2}$.

\subsection{Cell Characterization by Flow Cytometry}

Adherent monocytes-derived cells were detached with $2 \mathrm{mM}$ EthylenedDiamine TetraAcetic acid-Phosphate Buffer Saline (EDTA-PBS) $(v / v)$ and incubated with anti-CD14 (1:100; 555397, BD Bioscience, Franklin Lakes, NJ, USA), anti-CD31 (1:100; FAB3567A, R\&D Systems, Abingdon, UK), anti-VE- (Vascular-Endothelial Cadherin) (1:100; FAB1002A, R\&D Systems), anti-KDR (Kinase insert Domain Receptor) (1:100; FAB357A, R\&D Systems), anti-CD68 (1:100; 333810, Biolegend, San Diego, CA, USA), anti-CD80 (1:100; 305206, BioLegend), and anti-CD163 (1:100; 333626, Biolegend). Briefly, cells were incubated with antibodies in 0.5\% PBS-Bovine Serum Albumin (BSA) (A9647, Sigma-Aldrich) $(v / w)$, for $20 \mathrm{~min}$, in dark at $4{ }^{\circ} \mathrm{C}$. Von Willebrand factor (vWF; or factor VIII) detection was performed with anti-vWF (1:500; A0082, Dako-Agilent, Santa Clara, CA, USA), for $60 \mathrm{~min}$ at $4{ }^{\circ} \mathrm{C}$ with gentle shaking. After incubation, cells were rinsed and re-incubated with a secondary antibody (Alexa Fluor ${ }^{\circledR} 488$ anti-rabbit-A-11078, Invitrogen-Thermo Fisher Scientific), for $30 \mathrm{~min}$ at $4{ }^{\circ} \mathrm{C}$ and in the dark with gentle shaking. The immunolabelling was evaluated by flow cytometry (FACScalibur-Becton Dickinson, Franklin Lakes, NJ, USA) and data were analysed using FlowJo (http://www.flowjo.com/) software (Becton Dickinson).

\subsection{Reverse Transcription and Quantifying PCR (RT-qPCR)}

Total RNA was extracted using a RNeasy Mini Extraction kit (74,104; Qiagen, Hilden, Germany) and cDNA was synthesized using SuperScript II Reverse Transcriptase (18080e44, Invitrogen-Thermo Fisher Scientific), according to the manufacturer's protocol. Relative quantification using qPCR was performed using Power SYBR Green PCR Master Mix (4367659, Applied Biosystems-Thermo Fisher Scientific), according to manufacturer's instructions, and carried out in a LightCycler 480 instrument (Roche, Basel, Swiss). The primers used are presented in Table 1. 
Table 1. List of primers used for RQ-PCR.

\begin{tabular}{ccc}
\hline Primer & Foward & Reverse \\
\hline CXCR4 & CTCCAAGCTGTCACACTCCA & TCGATGCTGATCCCAATGTA \\
\hline CSF-1 & GTCTTCCACCTGCTGGTGC & CCCTCTGGTTGCTCCAAGG \\
\hline FLT1 & CACCAAGAGCGACGTGTG & TTTTGGGTCTCTGTGCCAG \\
\hline Hes1 & ACGACACCGGATAAACCAAA & CGGAGGTGCTTCACTGTCAT \\
\hline Ang1 & GGGGAGGTTGGACTGTAATAC & GCATGTACTGCCTCTGACTG \\
\hline Dll1 & ATGCCTTCGGCCACTTCAC & CACATCCAGGCAGGCAGAT \\
\hline Notch1 & TGGCGGGAAGTGTGAAGCGG & GTGCTGAGGCACGGGTTGGG \\
\hline Notch2 & CCACAGGTGTCAGAATGGAG & GGCATTCATCCACATCCTCTG \\
\hline Hey1 & GACGAGACCGGATCAATAACAG & GGTCATCTGCAGGATCTCG \\
\hline Hey2 & GAGCGAGAACAATTACTCGGG & GTTATTTATCCGATCCCGACGC \\
\hline FGFR4 & GATGCTCAAAGACAACGCCTC & GACACCAAGCAGGTTGATGATG \\
\hline 185 & GCCCTATCAACTTTCGATGGT & CCGGAATCGAACCCTGATT \\
\hline
\end{tabular}

\subsection{D Co-Culture and Microencapsulation}

For the co-cultures, HCC1954 cells were inoculated at a density of $0.2 \times 10^{6}$ cell/mL in a $125 \mathrm{~mL}$ impeller spinner vessel (Corning) and aggregated at $80 \mathrm{rpm}$ for 4 days. The spheroids were then co-cultured with human derived monocytes and encapsulated in $1.1 \%(w / v)$ Ultra-Pure $\mathrm{Ca}^{2+}$ medium viscosity high-guluronic acid (MVG) alginate (UP MVG NovaMatrix, Pronova Biomedical, Avaldsnes, Norway), prepared in $\mathrm{NaCl} 0.9 \%(w / v)$. The alginate microencapsulation was performed on a VARV1 encapsulator (Nisco, Zurich, Switzerland) to obtain capsules of approximately $700 \mu \mathrm{m}$ and the polymerization occurred in a $20 \mathrm{mM} \mathrm{BaCl}_{2}$ solution. After polymerization, the capsules were washed in $\mathrm{NaCl}$ 0.9\% (w/v) and cultured in RPMI 1640, in $125 \mathrm{~mL}$ vented cap Erlenmeyer flasks (Corning) at 100 $\mathrm{rpm}$, in orbital agitation. After culture, samples were collected and fixed in $4 \%(w / v)$ formaldehyde with $4 \%(w / v)$ sucrose in PBS for $20 \mathrm{~min}$. Then, they were dehydrated in 30\% $(w / v)$ sucrose for approximately $5 \mathrm{~h}$ and embedded in Tissue-Tek ${ }^{\circledR}$ O.C.T. (Sakura, Saint Torrance, CA, USA) and frozen at $-80{ }^{\circ} \mathrm{C}$ for cryosectioning. The frozen samples were sliced with a thickness of $10 \mu \mathrm{m}$ in a cryostat (Cryostat CM 3050 S, Leica, Wetzlar, Germany).

\subsection{Murine (BALB-c \SCID) Model of Neo-Angiogenesis}

The animal handling and experimental procedures were performed under the rules of Federation for Laboratory Animal Science Associations (FELASA), accomplishing the 3Rs through evidence-based guidelines. Ethical committee NOVA Medical School (Ref. 75/2019/CEFCM) Female BALB-c/SCID mice (8 weeks) were maintained in a pathogen-free barrier room in the Animal Care Facility at Chronic Diseases Research Center (CEDOC)|NOVA-Medical School (NMS).

In the plug assay, monocytes isolated from the peripheral blood of healthy donors $\left(1 \times 10^{6}\right.$ cells/mice) were previously cultured for $24 \mathrm{~h}$ in EBM-2 supplemented with $50 \mathrm{ng} / \mathrm{mL}$ VEGF plus $10 \mathrm{U} / \mathrm{mL}$ heparin. After, cells were embedded in $400 \mu \mathrm{L}$ of matrigel supplemented with $50 \mathrm{ng} / \mathrm{mL}$ VEGF and subcutaneously inoculated in the right flank of the mice for 21 days. Control groups were inoculated with matrigel supplemented with VEGF. Plugs were removed by surgery and fixed with $2 \%$ paraformaldehyde for $10 \mathrm{~min}$, followed by successive $15 \mathrm{~min}$ incubations in $100 \%, 95 \%$, and $60 \%$ ethanol and then processed into paraffin-embedded blocks.

Breast tumors were induced by inoculation of MDA-MB-231 cells in the mammary fat pad. Female mice were injected with $50 \mu \mathrm{L}$ of matrigel with breast cancer cells (MDA-MB-231, $1 \times 10^{6}$ cells/mice) alone and in combination with monocytes, which were previously cultured for $24 \mathrm{~h}$ in EBM-2 supplemented with $50 \mathrm{ng} / \mathrm{mL}$ VEGF (MDA-MB-231, $1 \times 10^{6}$ cells/mice plus monocytes $1 \times 10^{4}$ cells/mice). Tumors 
were removed by surgery 45 days after inoculation and fixed with formaldehyde with further inclusion in paraffin-embedded blocks. The tumor volume was calculated using the formula: tumor volume = $\left(\right.$ length $\times$ width $\left.^{2}\right) / 2$.

\subsection{Immunofluorescence}

In vitro cells were cultured on glass slides with $0.2 \%$ gelatin coating and fixed in $2 \%$ PFA, for $15 \mathrm{~min}$ at $4{ }^{\circ} \mathrm{C}$. After blocking, cells were incubated with primary antibodies diluted in $0.1 \%$ BSA-PBS $(v / w)$, overnight (1:100-CD14, ab181470, Abcam, Cambridge, UK; 1:50 -CD31, SCR023, Merck Millipore, Burlington, mA, USA; 1:500-vWF, SCR023, Merck Millipore; 1:500-CD146, SCR023, Merck Millipore), followed by an incubation with secondary antibody for $2 \mathrm{~h}$ (1:1000 0.1\% BSA-PBS (v/w), Alexa Fluor ${ }^{\circledR} 594$ goat anti-rabbit, A-11037, Invitrogen-Thermo Fisher Scientific; Alexa Fluor ${ }^{\circledR} 488$ goat anti-rabbit, A-11078, Invitrogen-Thermo Fisher Scientific; Alexa Fluor ${ }^{\circledR} 488$ goat anti-mouse, 115-545-003, Invitrogen-Thermo Fisher Scientific), at room temperature.

Paraffin sections $(2 \mu \mathrm{m})$ were deparaffinized in xylol for $30 \mathrm{~min}$ and re-hydrated in decreased concentrations of ethanol (95\%,70\%, and 30\%), followed by an immersion in water and antigen recovery using citrate buffer. Slides were blocked with 5\% BSA-PBS (w/v) for $30 \mathrm{~min}$ to avoid non-specific interactions, followed by an incubation with $0.3 \mathrm{M}$ glycine-goat serum- $0.1 \%$ Triton $\times 100$, for $30 \mathrm{~min}$. After, slides were incubated with primary antibodies diluted in 1\% BSA-PBS (v/w) (vWF-1:200, A0082; Dako; FN-1:50, SAB4500974, Sigma-Aldrich), for $1 \mathrm{~h}$ at room temperature followed by an incubation with secondary antibody (1:500 in 1\% BSA-PBS $(v / w)$; Alexa Fluor ${ }^{\circledR} 488$ goat anti-rabbit; Alexa Fluor ${ }^{\circledR}$ 594 goat anti-rabbit-A-11037, Invitrogen-Thermo Fisher Scientific), for $2 \mathrm{~h}$, at room temperature. Slides were mounted in VECTASHIELD media with DAPI (4'-6-diamidino-2-phenylindole; Vector Labs) and examined by standard fluorescence microscopy using an Axio Imager.Z1 microscope (Zeiss, Oberkochen, Germany). Images were acquired and processed with CytoVision ${ }^{\circledR}$ software (Leica).

\subsection{Murine (BALB-c \SCID) Aorta Ex Vivo Model of Vascular Repair}

Endothelial injury was induced in murine aortas, longitudinally open, through the exposure to Lipopolyssacharides (LPS) $(0.5 \mu \mathrm{g} / \mathrm{mL}$; L2880-Sigma-Aldrich) plus Lysophosphatidic acid (LPA) $(0.5 \mu \mathrm{g} / \mathrm{mL}$; L7260-Sigma-Aldrich), over $24 \mathrm{~h}$. Afterwards, aortas were rinsed with $1 \times$ PBS and embedded in Matrigel with $50 \mathrm{ng} / \mathrm{mL}$ VEGF plus $10 \mathrm{U} / \mathrm{mL}$ heparin with human Day 3 monocytes, cultured in EBM2 supplemented with 50 ng/mL VEGF plus $10 \mathrm{U} / \mathrm{mL}$ heparin, for 5 days. Aortas were removed from Matrigel and fixed with $4 \%$ paraformaldehyde (PFA) for $2 \mathrm{~h}$, and rinsed with blocking buffer $(1 \times$ PBS $+10 \%$ horse serum $+0.3 \%$ Triton $\mathrm{X}-100)$. The aortas were incubated with primary antibody diluted in 1\% BSA-PBS ( $v / w)$ (vWF-1:200, A0082; Dako), overnight at $4{ }^{\circ} \mathrm{C}$, followed by two times rinsing with blocking buffer and a $2 \mathrm{~h}$ incubation with secondary antibody (1:500 in 1\% BSA-PBS $(v / w)$; Alexa Fluor ${ }^{\circledR} 594$ goat anti-rabbit) at room temperature. After the final washes with blocking buffer, aortas were mounted in slides with in VECTASHIELD media with DAPI. Images were acquired using an LSM 710 (Zeiss) confocal microscope equipped with a Plan-Apochromat 63/1.40 Oil Ph3 lens and Zen Blue 2010b SP1software (2010b; Zeiss).

\subsection{Fluorescence In Situ Hybridization (FISH)}

After immunofluorescence analysis, FISH using an alphoid probe for centromere X (pLAX) [33], and a probe for the Yq12 region (pHY2.1) [34] was applied to the same slides/tissue sections having anti-human vWF positive cells. The X-centromere probe was labeled with digoxigenin (DIG) and the Yq12 probe with biotin, as previously described [35]. Briefly, slides were incubated twice in 2xSSC for $5 \mathrm{~min}$ at room temperature to wash away the DAPI antifade solution, re-hydrated in ethanol series, and incubated in citrate buffer, in a water bath for $10 \mathrm{~min}$ at $90^{\circ} \mathrm{C}$. Enzymatic digestion was carried out with $4 \mathrm{mg} / \mathrm{mL}$ pepsin in $0.2 \mathrm{~N} \mathrm{HCl}(\mathrm{pH} 2.0)$ for $30 \mathrm{~min}$ at $37^{\circ} \mathrm{C}$. After that, $10 \mu \mathrm{L}$ diluted probes were co-denatured with the tissues at $90{ }^{\circ} \mathrm{C}$ for $5 \mathrm{~min}$ and hybridized at $37{ }^{\circ} \mathrm{C}$, overnight. Post-hybridization wash was performed in $2 \times \mathrm{SSC} / 0.3 \% \mathrm{NP}-40$ for $3 \mathrm{~min}$ at $73^{\circ} \mathrm{C}$ followed by a wash 
in $2 \times \mathrm{SSC} / 0.1 \% \mathrm{NP}-40$ for $2 \mathrm{~min}$ at room temperature. X-centromere DIG-labeled probe was detected by anti-digoxigenin-FITC (Fluorescein isothiocyanate) (Anti-digoxigenin- fluorescein, Fab fragments; 11270741910, Roche), biotinylated Yq12 probe was detected by Cy3-streptavidin (CyTM3-conjugated Streptavidin; 016-160-084, Jacksons Lab, Bar Harbor, ME, USA), and nuclei were counterstained with DAPI-vectashield mounting solution. FISH signals, in previously recorded immunofluorescence vWF and FN positive cells, were captured and analyzed using a Zeiss Epifluorescence microscope linked to a Cytovision FISH Probe software program (Cytovision version 7.4, Leica Biosystems, Richmond, VA, USA).

\subsection{Immunohistochemistry (IHC)}

Paraffin sections $(2 \mu \mathrm{m})$ from paraffin-embedded tissue blocks were deparaffinized, re-hydrated, as mentioned above, and antigen recovery was performed using citrate buffer. Slides were rinsed with $1 \times$ Tris Buffered Saline (TBS) followed by the blockage of endogenous peroxidase (K4011, Dako) for $10 \mathrm{~min}$. Anti-vWF (1:200 in IHC diluent) was incubated for $3 \mathrm{~h}$ and anti-fibronectin (FN; 1:50 in IHC diluent, RE7133-CE, Leica) for $1 \mathrm{~h}$, at room temperature. Staining was performed using ABC detection kit (ab93677, Merck Millipore), according to the manufacturer's protocol. For nuclear staining, slides were immersed in Mayer's Hematoxylin (RE7164, Leica) for $5 \mathrm{~min}$. Slides were dehydrated and mounted with Entellan (1079610500, Merck) and digitalized using Aperio ImageScope-Pathology Slide Viewing software version 12.4 (Leica, Wetzlar, Germany).

\subsection{Data Statistical Analysis}

Data were analyzed using t-test and one-way ANOVA tests in GraphPad Prism 7 software (7, Prism GraphPad, San diego, CA, USA). Statistically significant changes were determined at the $p$ value $\leq 0.05$.

\section{Results}

\subsection{In Vitro Monocytes Differentiate into Endothelial Cells (ECs)}

Freshly isolated monocytes from healthy donors and HUVECs showed a similar profile of endothelial and macrophage markers, with the exceptions of CD14 and vWF that were more expressed, respectively, in monocytes and in HUVECs (Figure 1A,B and Figure S1), pointing out that monocytes cultured in a pro-endothelial medium share molecular features with ECs. Notably, monocytes cultured in CFU media, a media for the maintenance of stem and progenitor cells, had lower expression of endothelial and macrophage markers (Figure 1A), indicating the maintenance of a resting and more undifferentiated state.

Monocytes cultured in matrigel plus VEGF presented a spindle-cell-like morphology (Figure 1C), typical of tip ECs. In the line with the morphological changes observed in cultured monocytes, a dynamic CD31 gain and CD14 loss was observed during 17 days in culture, in the presence of VEGF (Figure 1D). The increase of endothelial markers vWF and CD146 with a concomitant decrease of monocytic marker CD14, were also observed at 15 days of culture, under VEGF stimuli (Figure 1E). In addition, VEGF drives an increase in the expression of endothelium-expressed genes (Notch1, Delta 1 (Dl11), Hes Family BHLH Transcription Factor 1 (Hes1), Hairy/enhancer-of-split related with YRPW motif protein 2 (Hey2), Fms Related Tyrosine Kinase 1 (FLT1), and Colony-Stimulating Factor (CSF)-1) (Figure 1F), which is in accordance with the morphological changes observed in monocytes-derived cells (Figure 1C,D). 
A

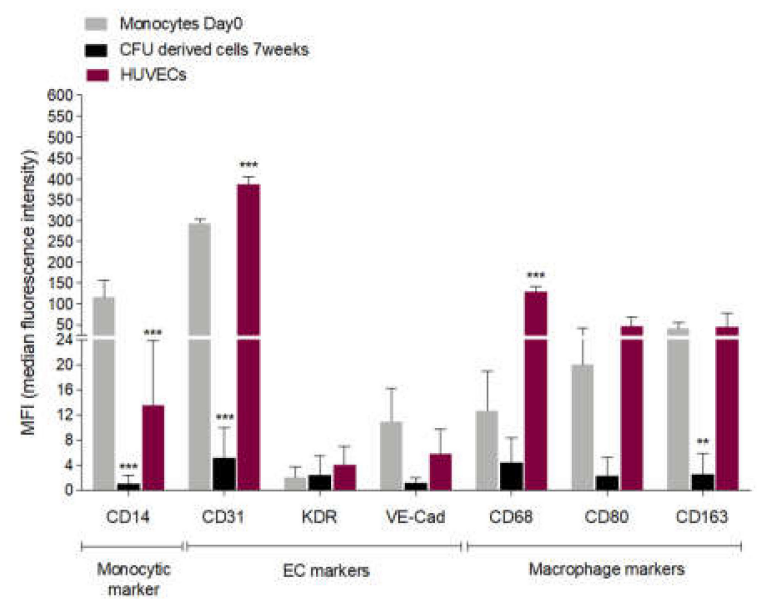

B

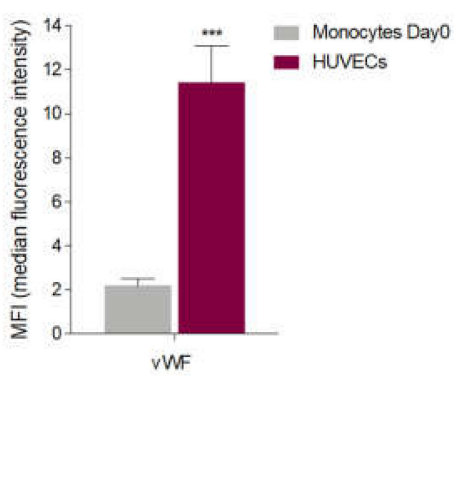

C

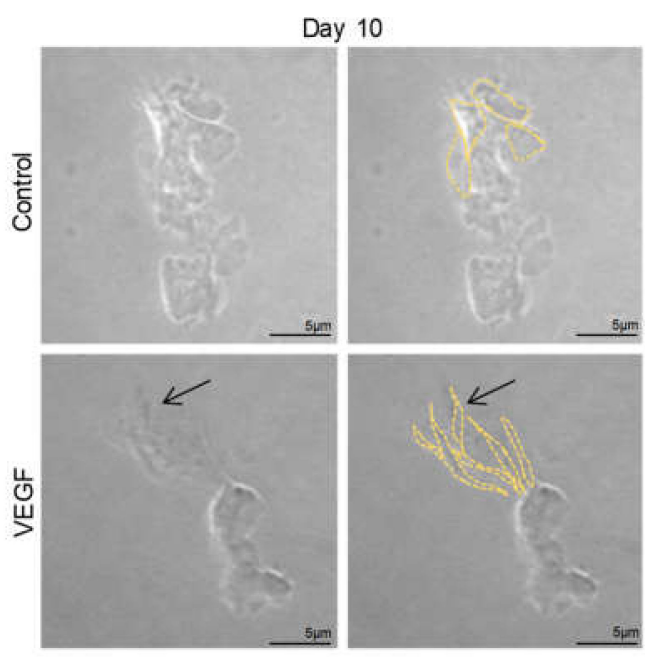

D

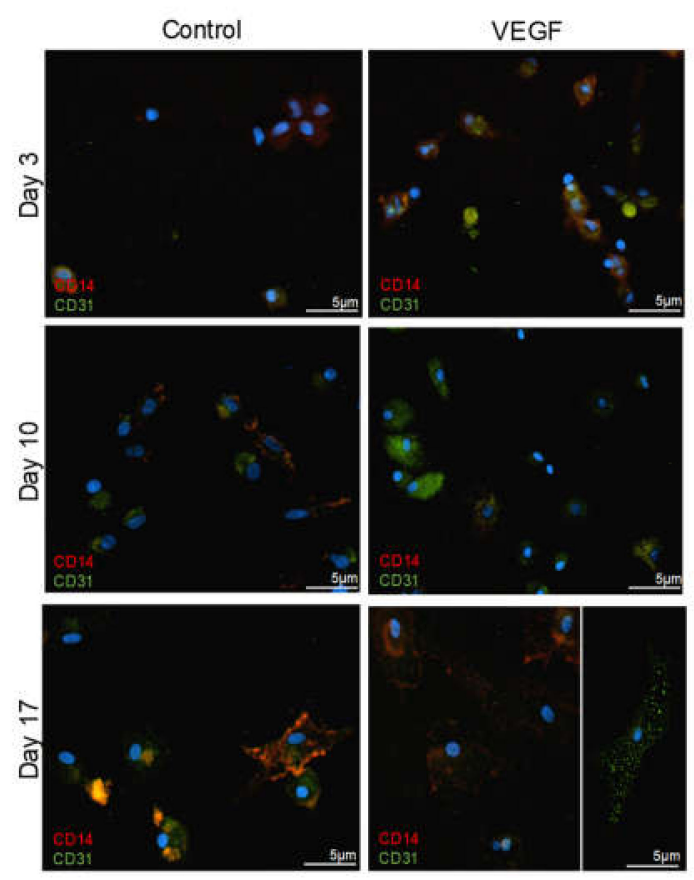

Figure 1. Cont. 
E

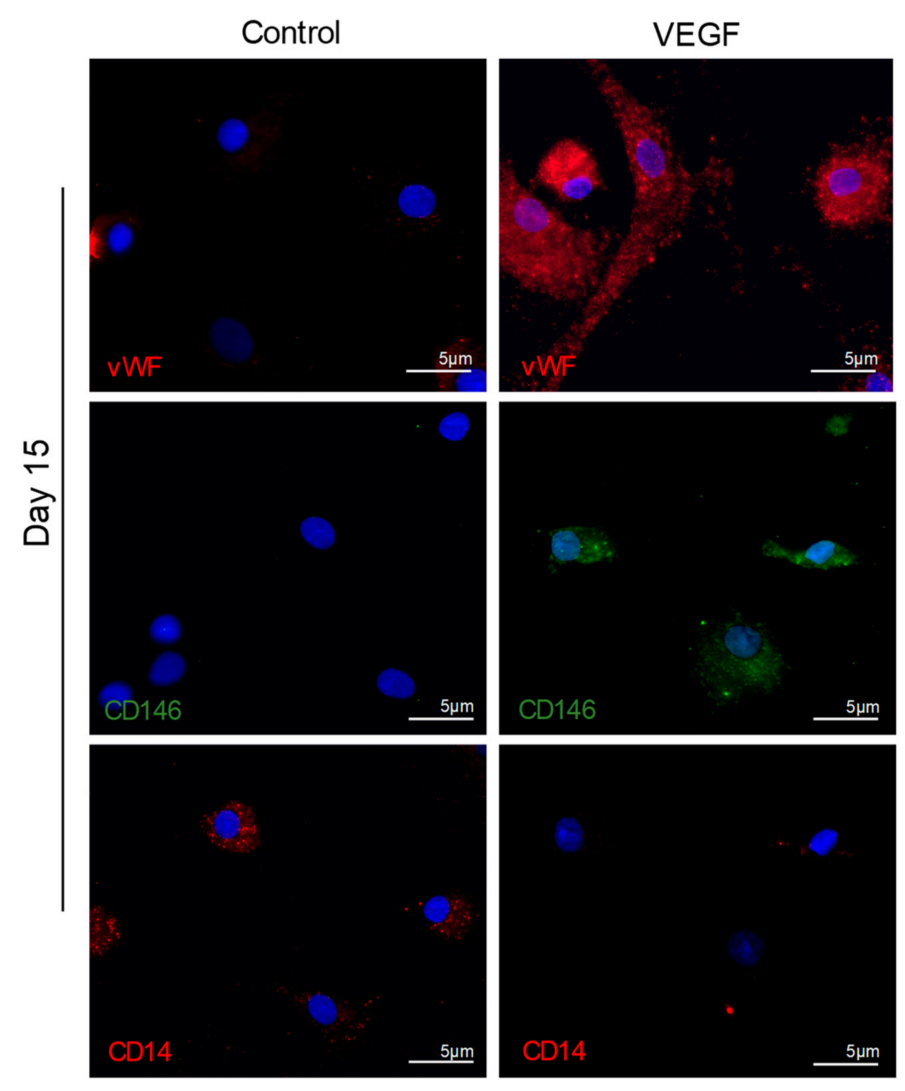

$\mathrm{F}$

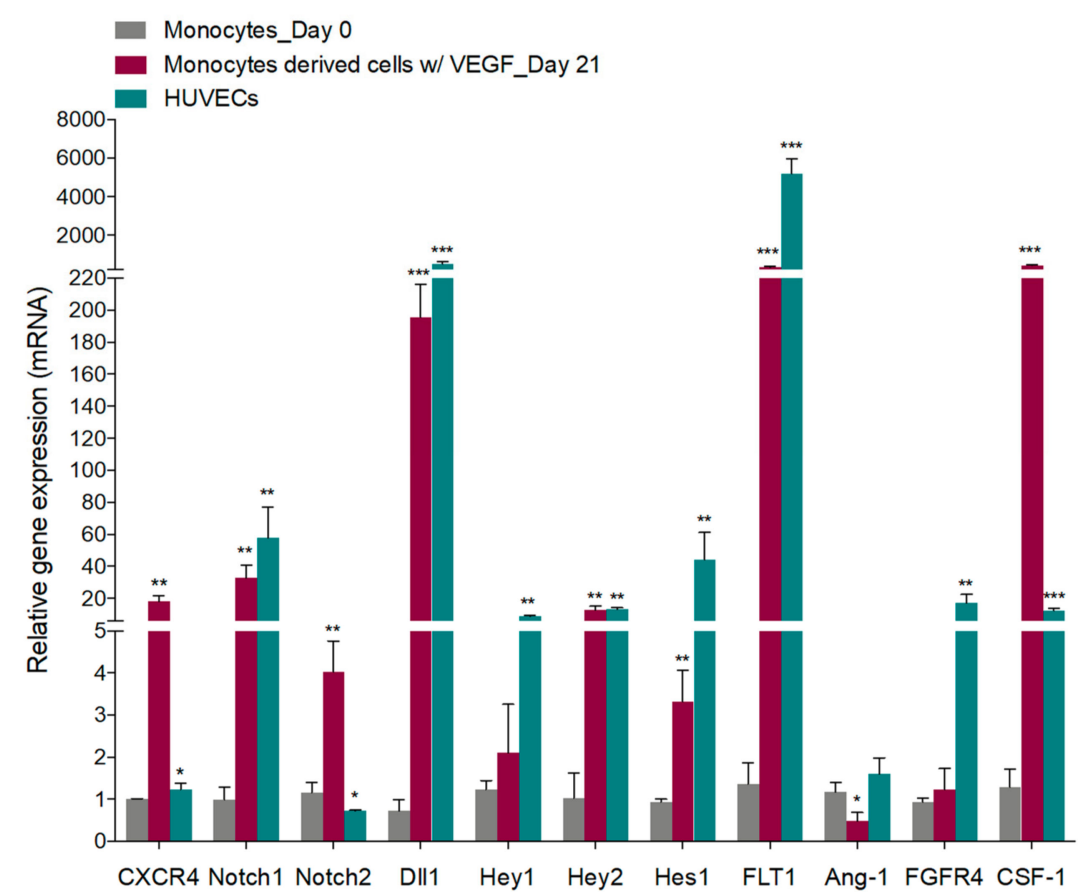

Figure 1. Cultured monocytes undergo an increase in the expression of endothelial cells (ECs) markers and acquire spindle cell like morphology, indicating EC differentiation of monocytes. (A) MIF (median intensity fluorescence) values from Flow cytometry analysis of CD14-monocytic marker, CD31, KDR, 
VE-Cadherin (VE-Cad) -EC markers and CD68, CD80, and CD163-macrophage markers in monocytes freshly isolated (Day 0), monocytes maintained in CFU media and in human umbilical vein ECs (HUVECs). (B) MIF (median intensity fluorescence) values from FACS analysis of vWF-EC marker in monocytes freshly isolated (Day 0), and in human umbilical vein ECs (HUVECs). (C) Monocytes cultured for 10 days in Matrigel in EBM-2 medium with or without VEGF. Images taken under optical microscopy, magnification 200x; arrow shows spindle shape cells (bars $5 \mu \mathrm{m}$ ). (D) Immunofluorescence for CD14 (red) and CD31 (green) in monocytes cultured in EBM-2 medium with or without VEGF for 3, 10 and 17 days (bars $5 \mu \mathrm{m}$ ). DAPI (blue) stained nuclei, magnification 400×. (E) Immunofluorescence for CD14 (red) and CD31 (green) in monocytes cultured in EBM-2 medium with or without VEGF for 3, 10 and 17 days (bars $5 \mu \mathrm{m}$ ). DAPI (blue) stained nuclei, magnification 400×. (F) Relative quantification of typical endothelial genes in monocytes freshly isolated (Day 0), in monocytes-derived cells cultivated for 21 days in the presence of VEGF and in HUVECs. ${ }^{*} p \leq 0.05^{* *} p \leq 0.01{ }^{* * *} p \leq 0.001$.

\subsection{Reactive Oxygen Species (ROS) Promote Monocytes Differentiation into Endothelial Cells (ECs)}

Monocyte-derived cells were exposed to $\mathrm{H}_{2} \mathrm{O}_{2}$ in short term, for $30 \mathrm{~min}$, and showed EC differentiation. This fact was observed in monocytes previously maintained in CFU for 4 days (Day 4) and in monocytes maintained in CFU for 4 days plus 1 day in EBM-2 media (Day 5). The increase in von Willebrand factor (vWF) expression was 5.9- and 4.4-fold, respectively (Figure 2A). The expression of other EC markers, such as CD31 and CD146, was also increased, and CD14 expression was decreased after $\mathrm{H}_{2} \mathrm{O}_{2}$ stimulus (Figure 2B). Cysteine, which is a thiol, precursor of glutathione, and itself an antioxidant, abrogates the $\mathrm{H}_{2} \mathrm{O}_{2}$-induced differentiation process, with no increase in vWF expression (Figure 2C).

Aldehyde dehydrogenase (ALDH) is used as a marker for populations enriched in stem and progenitor cells and a decrease in ALDH expression and activity is correlated with a differentiation status of EPCs to ECs [36,37]. Hence, the impact of ALDH inhibition by disulfiram [38] was evaluated in the monocyte-endothelial differentiation. Monocytes from Day 4 (Figure 2D) and Day 5 (Figure 2E) exposed to disulfiram showed a gain of vWF expression similar to monocytes exposed to $\mathrm{H}_{2} \mathrm{O}_{2}$, reinforcing that monocytes are differentiating into ECs. 
A

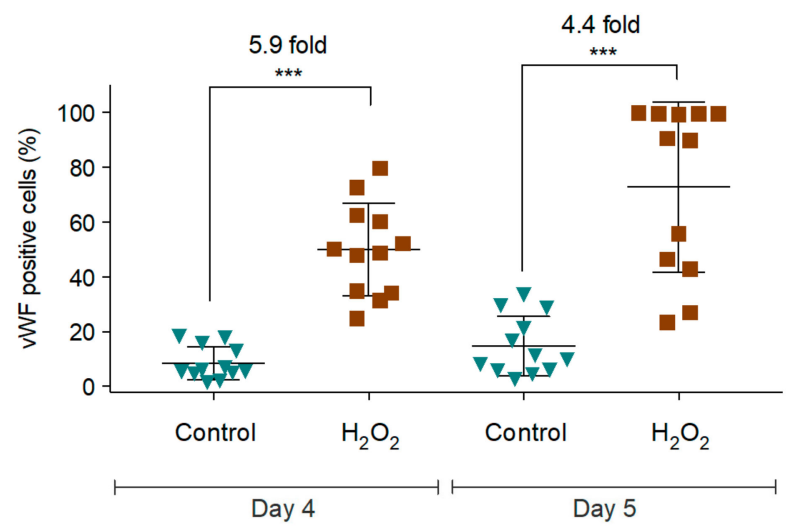

B

Control

$\mathrm{H}_{2} \mathrm{O}_{2}$
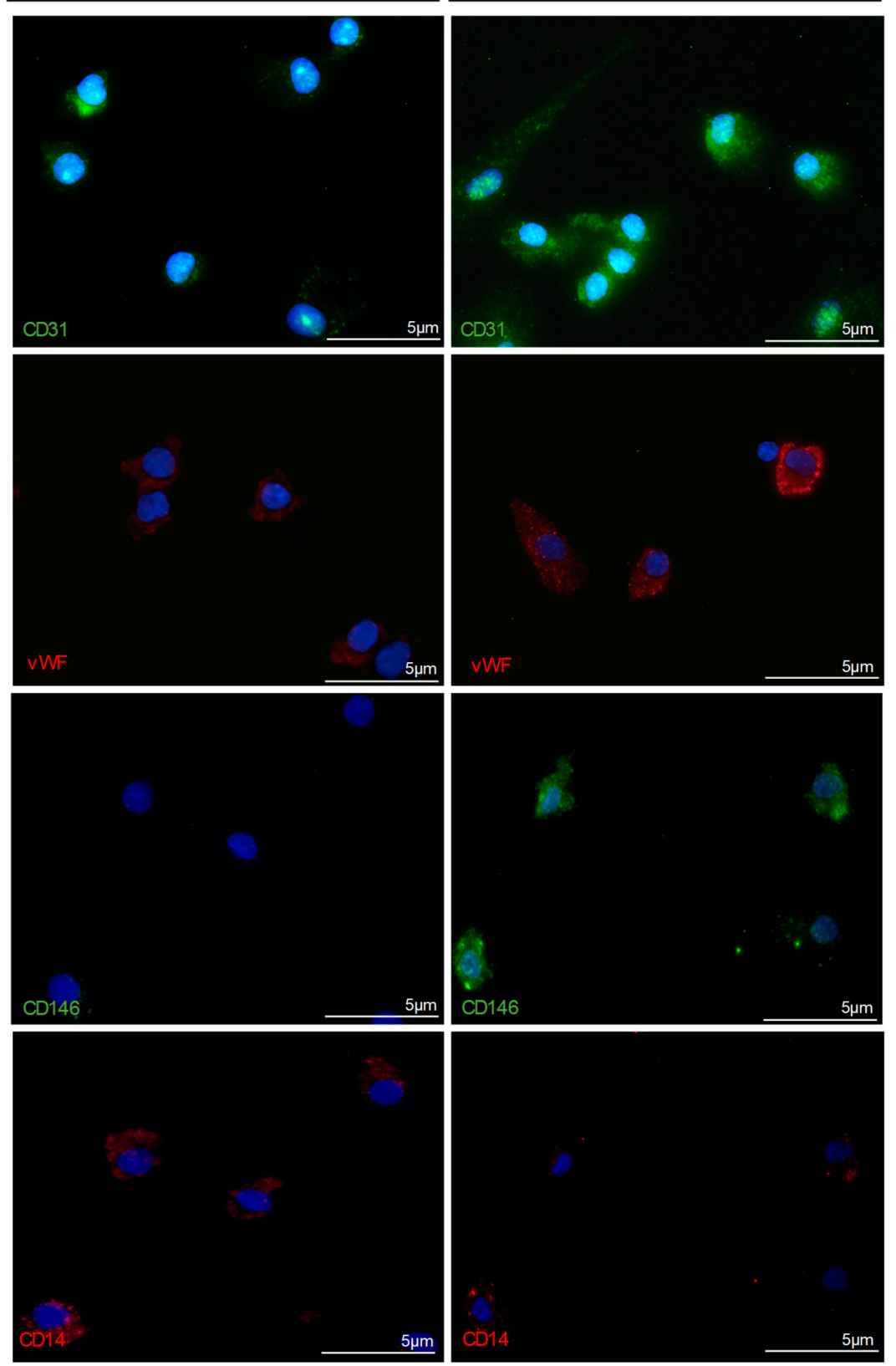

Figure 2. Cont. 

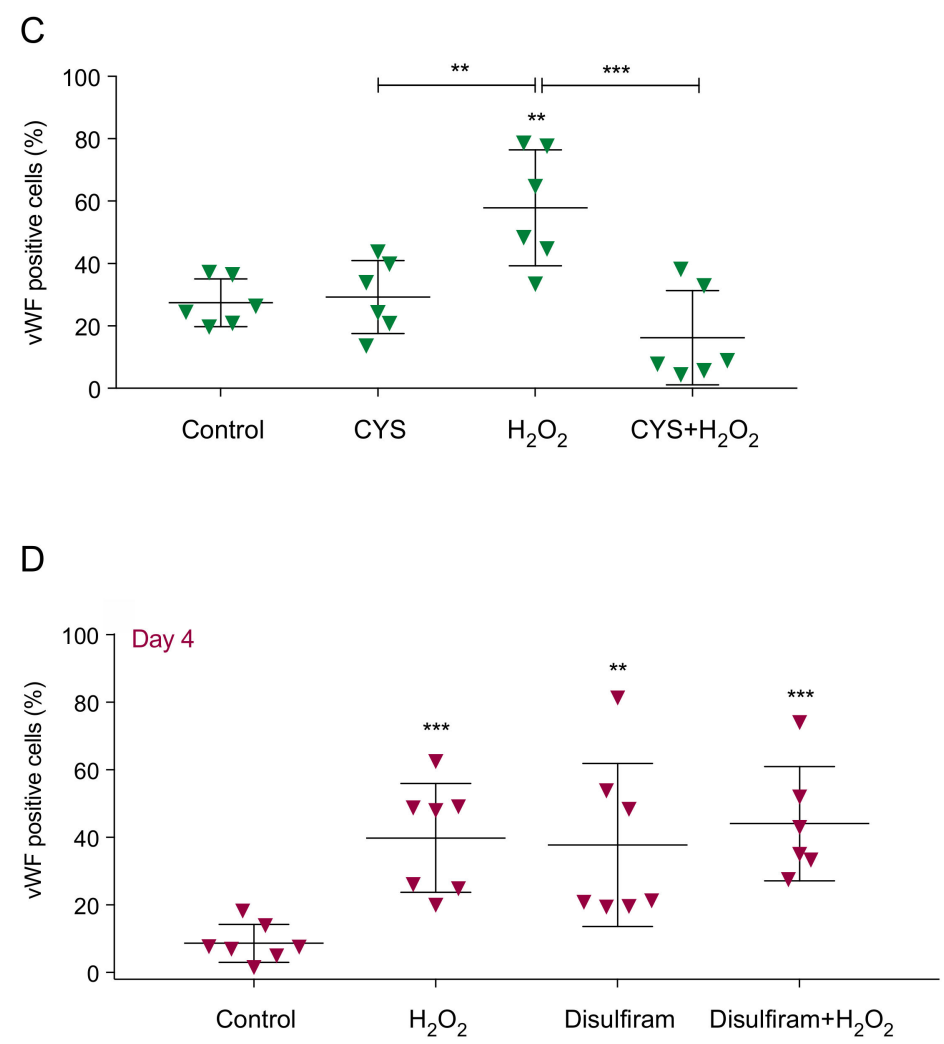

E

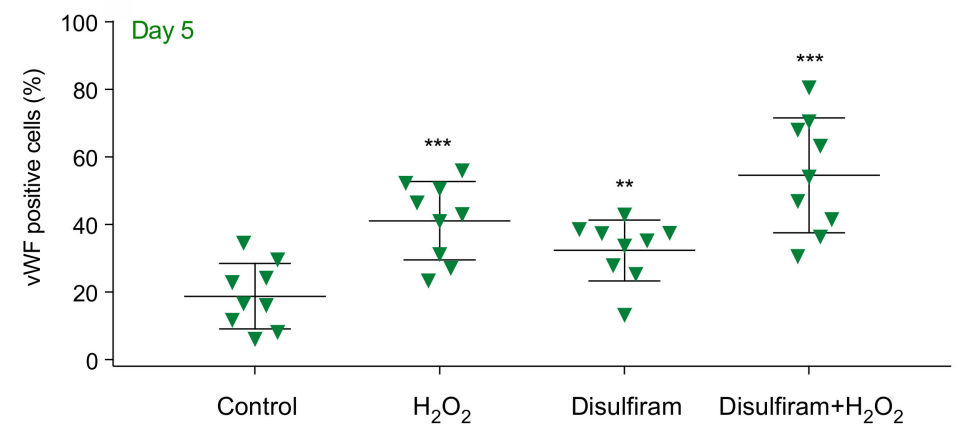

Figure 2. Monocyte-derived cells cultured in the presence of hydrogen peroxide $\left(\mathrm{H}_{2} \mathrm{O}_{2}\right)$ increase the expression of endothelial cell (EC) markers that is abolished by the presence of cysteine (Cys). (A) vWF levels in monocytes-derived cells maintained in CFU media (Day 4) plus 1 day in EBM-2 plus VEGF (Day 5), in the presence or absence of $\mathrm{H}_{2} \mathrm{O}_{2}(15 \mu \mathrm{M})$. (B) Immunofluorescence for CD31 (green), vWF (red), CD146 (green) and CD14 (red) in monocytes cultured during 5 days in EBM-2 medium with VEGF, in the presence or absence of $\mathrm{H}_{2} \mathrm{O}_{2}(15 \mu \mathrm{M})$. Nuclei are in blue (DAPI), magnification 400× (bars $5 \mu \mathrm{m})$. (C) vWF levels in monocytes-derived cells maintained in EBM-2 plus VEGF, in the presence and/or absence of Cys $(0.4 \mathrm{mM})$ and $\mathrm{H}_{2} \mathrm{O}_{2}(15 \mu \mathrm{M})$ for 1 day. $(\mathbf{D} / \mathbf{E}) \mathrm{vWF}$ levels in monocytes-derived cells maintained in CFU media (Day 4) plus 1 day in EBM-2 plus VEGF (Day 5), in the presence or absence of $\mathrm{H}_{2} \mathrm{O}_{2}(15 \mu \mathrm{M})$ and/or disulfiram $(2 \mu \mathrm{M})$. Each dot represents a healthy donor. ${ }^{* *} p \leq 0.01$ $* * * \leq 0.001$.

\subsection{In Vivo, Monocytes Differentiate into ECs and Are Incorporated into Blood Vessels}

Matrigel plugs with embedded human monocytes from male healthy donors were subcutaneously inserted in mice; control plugs were induced with matrigel solely. Macroscopically, plugs with human monocytes exhibited a more exuberant vasculature (Figure 3A) and, microscopically, an increased 
density of vessel-like structures was observed (Figure 3B,C). Some of the vessel-like structures in plugs containing monocytes were positive for the human vWF (hvWF) (Figure 3D,E and Figure S2), indicating that human monocytes differentiate into ECs and were incorporated into blood vessels. It is noteworthy that the vessel-like structures in control plugs (Figure 3A-C), were negative for hvWF (Figure 3D,E), which confirmed their murine origin. Additionally, vessel-like structures of the control and monocytes group were positive for fibronectin (FN) (Figure 3D,E), a protein of the vessels basement membrane that is expressed by active ECs $[39,40]$, indicating that those structures are new-formed vessels.

A
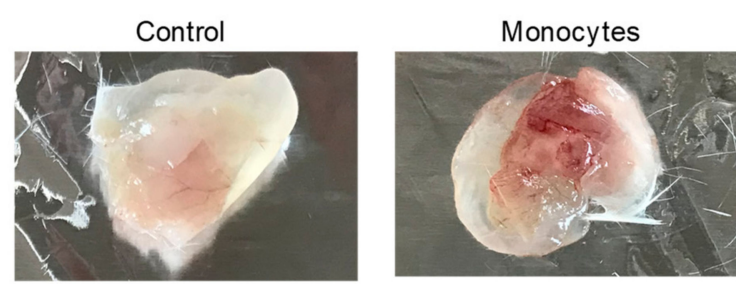

B

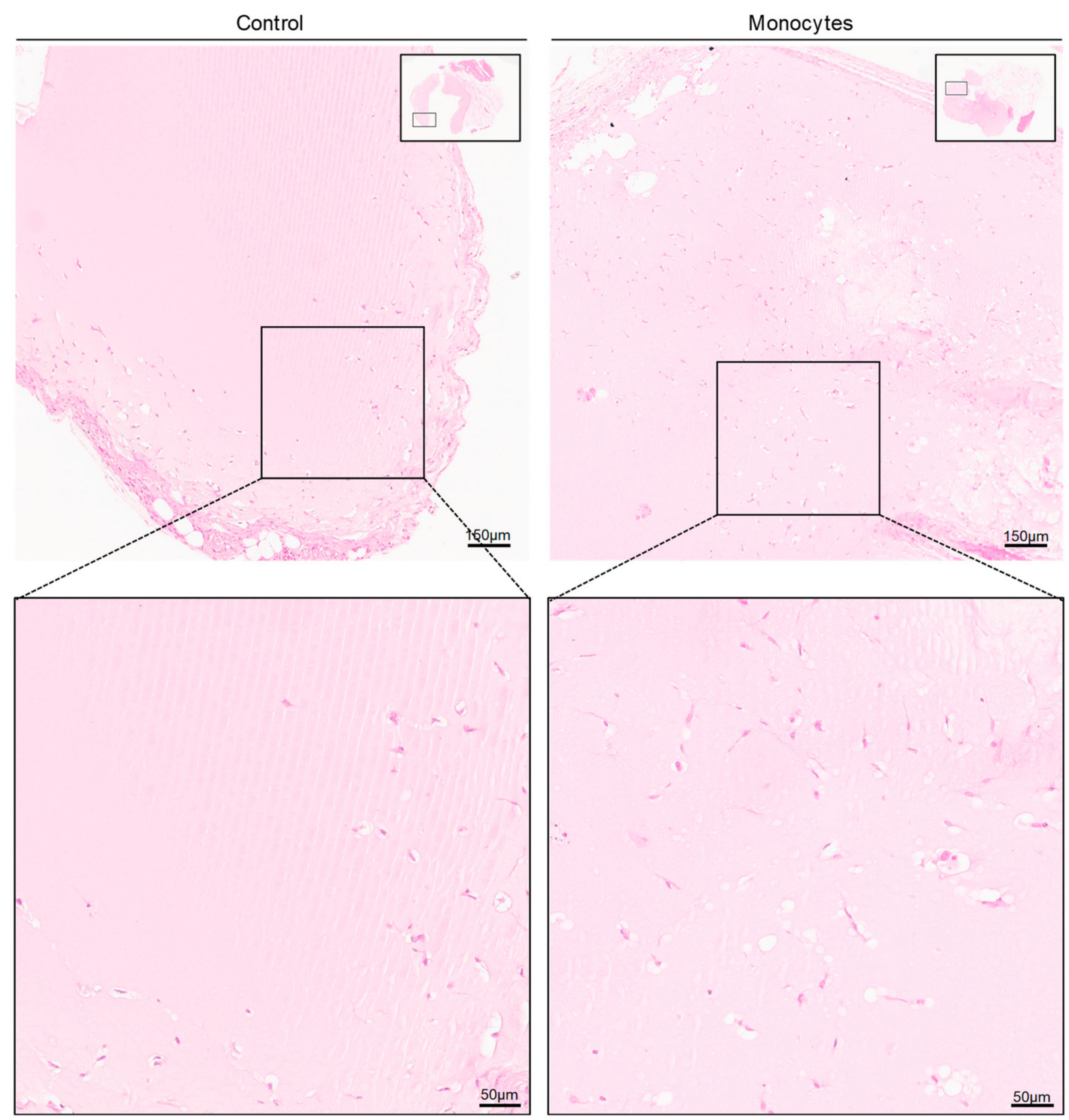

Figure 3. Cont. 


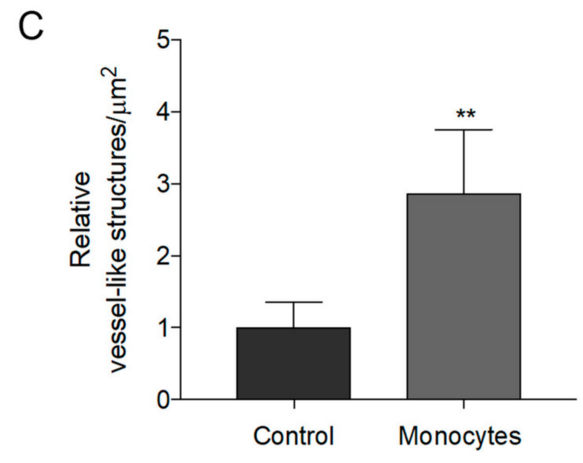

D

$\sum_{\geq}^{u}$

누

Figure 3. Cont. 
E
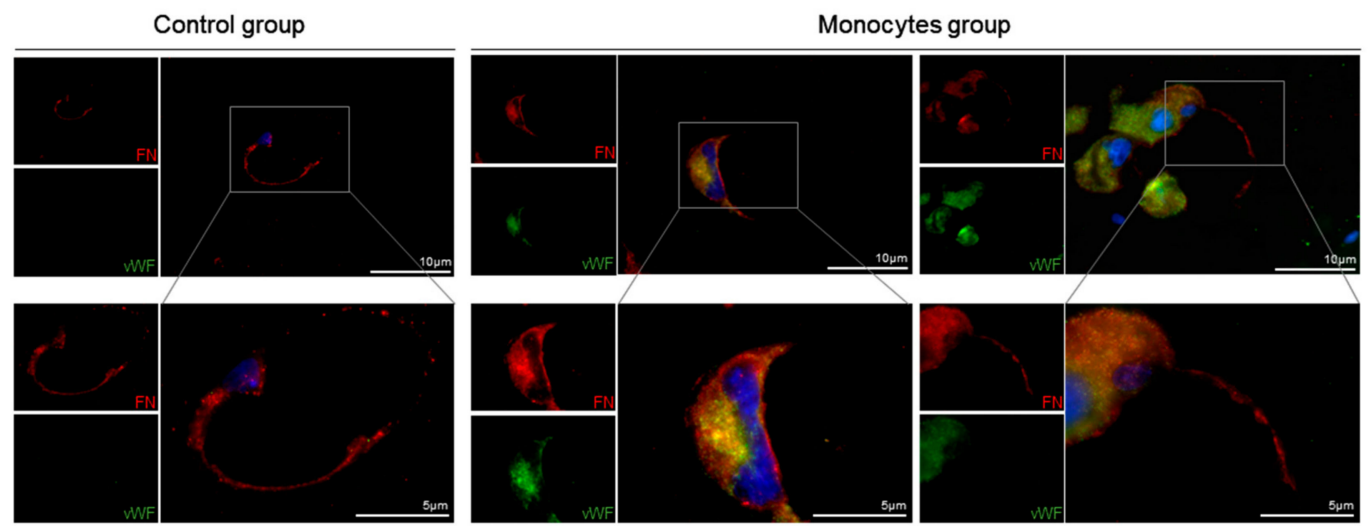

$\mathrm{F}$
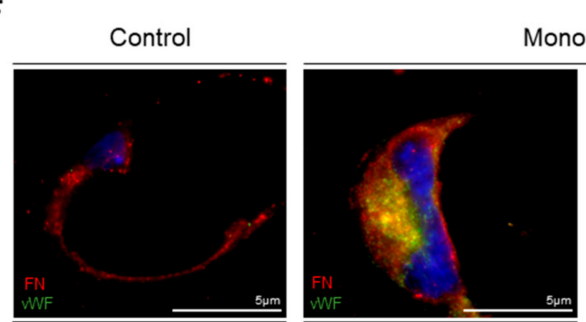

Monocytes
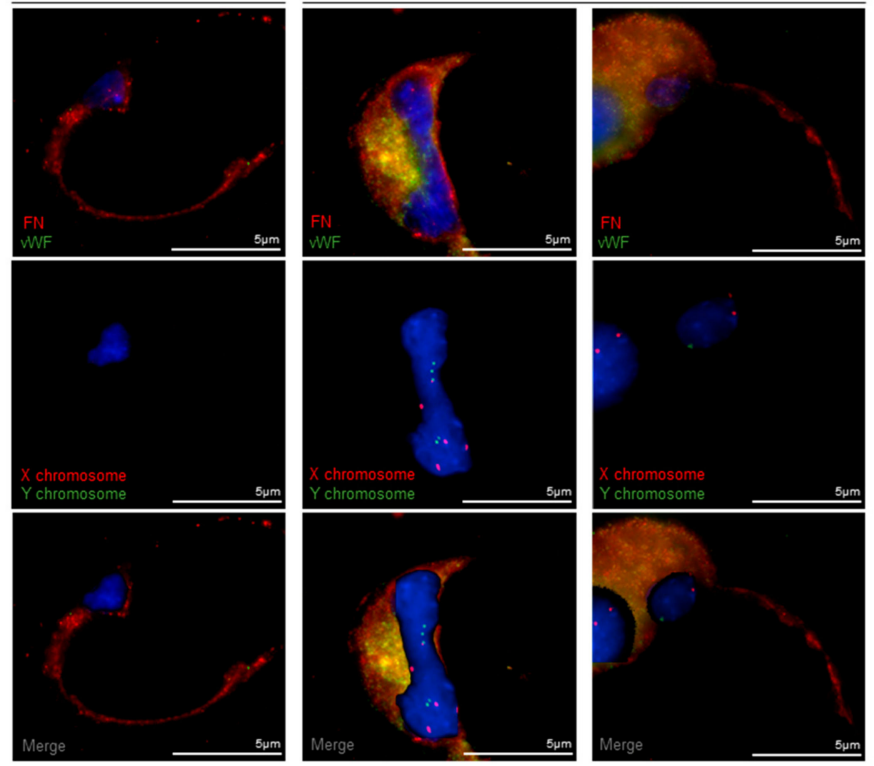

Figure 3. Monocytes exposed to VEGF are able to form blood vessels in vivo. (A) Plug images 21 days after monocyte inoculation in matrigel with VEGF. Control plugs were inoculated in the absence of monocytes. (B) Hematoxylin and eosin staining from the paraffin embedded plugs (bars $150 \mu \mathrm{m}$ and $50 \mu \mathrm{m})$. (C) Relative density of vessel-like structures per area $(\mu \mathrm{m})$ in plugs $(n=4$ per group). (D) Human CD31 (hCD31) by immunohistochemistry. Optical microscopy, nuclei are blue (hematoxylin) (bars $100 \mu \mathrm{m}$ ). (E) Human vWF (hvWF; green) and fibronectin (FN, red) staining by immunofluorescence in plug blood vessels (bars $10 \mu \mathrm{m}$ and $5 \mu \mathrm{m}$ ). (F) The same sections (E) were submitted to FISH analysis for the human X (red) and Y (green) chromosome (bars $5 \mu \mathrm{m}$ ). Nuclei are blue (DAPI). ${ }^{* *} p \leq 0.01$.

In addition to the hvWF expression in monocytes-derived ECs in vessel-like structures, the human and male origin was also confirmed by FISH (Figure 3F) performed with human specific $X$ and $Y$ probes. Thus, we confirmed that the hvWF positive cells, in plugs with monocytes group, were from human origin (X and Y positive; Figure $3 \mathrm{~F}$ ), proving that monocytes can directly differentiate into ECs. 


\subsection{Monocytes Are Able to Repair Injured Aortas}

In order to verify if monocytes were able to repair injured vessels, we used an ex vivo model of murine aorta injury, due to the exposure to LPA and LPS, which are considered inducer of endothelial dysfunction and injury [41-43]. Interestingly, we observed that monocytes incorporated damaged aortas and differentiated into endothelial cells, as revealed by the expression of human vWF (Figure 4).
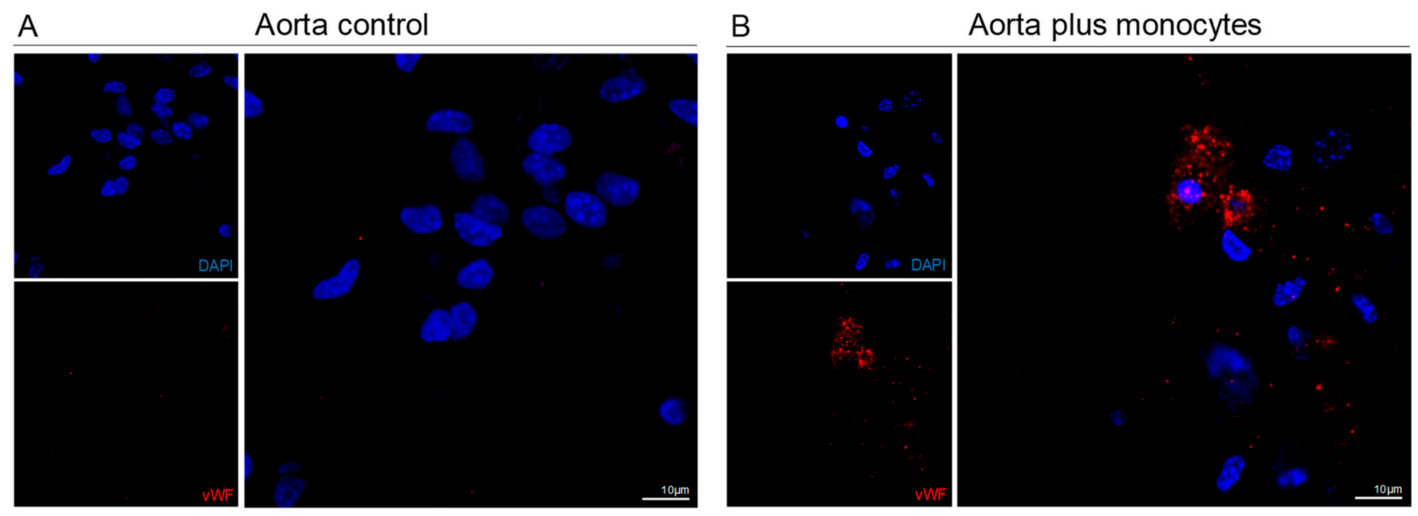

Figure 4. Monocytes are able to be incorporate in the aorta ex vivo, after endothelial Lipopolyssacharides/Lysophosphatidic acid (LPS/LPA)-related injury. Aortas were ex vivo exposed to LPS $(0.5 \mu \mathrm{g} / \mathrm{mL})$ plus LPA $(0.5 \mu \mathrm{g} / \mathrm{mL})$ to induce endothelial dysfunction. Afterwards LPS plus LPA were removed and monocytes were incubated with aortas. (A) Murine aorta section incubated with LPS plus LPA, showing no positive cells for human vWF (bars $10 \mu \mathrm{m})$. (B) Murine aorta section incubated with LPS plus LPA followed by incubation with monocytes, showing positive cells for human vWF (bars $10 \mu \mathrm{m}$ ). Nuclei are blue (DAPI).

\subsection{Monocytes Are Active Stakeholders in Neo-Vasculature Network Formation during Tumor Development}

To unravel the role of monocytes as EPCs in cancer context, we employed a 3D co-culture system [44] of human breast cancer cells (HCC1954) and human monocytes. In co-culture, hvWF positive cells also expressed FN (Figure 5A), which suggested that monocytes are differentiating into ECs. In control cultures (monocultures of HCC1954), FN labeling was detected but not vWF.

Also in vivo, we investigated if monocytes would be incorporated in the tumoral neo-vasculature, enhancing tumor development and growth. For that, we established a cancer model: Human breast cancer cells (MDA-MB-231) were inoculated in the mammary fat pad of female mice, in the presence or in the absence of human male monocytes. Mice injected with MDA-MB-231 and human monocytes developed larger tumors (4- and 2-fold at days 24 and 45, respectively; Figure 5B,C) in comparison to the mice inoculated only with MDA-MB-231. The percentage of necrotic area was similar in both experimental groups (Figure 5D); the total viable area was more extensive in tumors induced with MDA-MB-231 cells plus monocytes than in tumors induced only by MDA-MB-231 cells (Figure 5E). Remarkably, some ECs in tumor blood vessels of mice inoculated with MDA-MB-231 and monocytes were hvWF positive (Figure 5F; black arrow); in the cancer scenario, that indicates monocytes were able to differentiate into ECs and be incorporated into the neovasculature, contributing to tumor growth. 

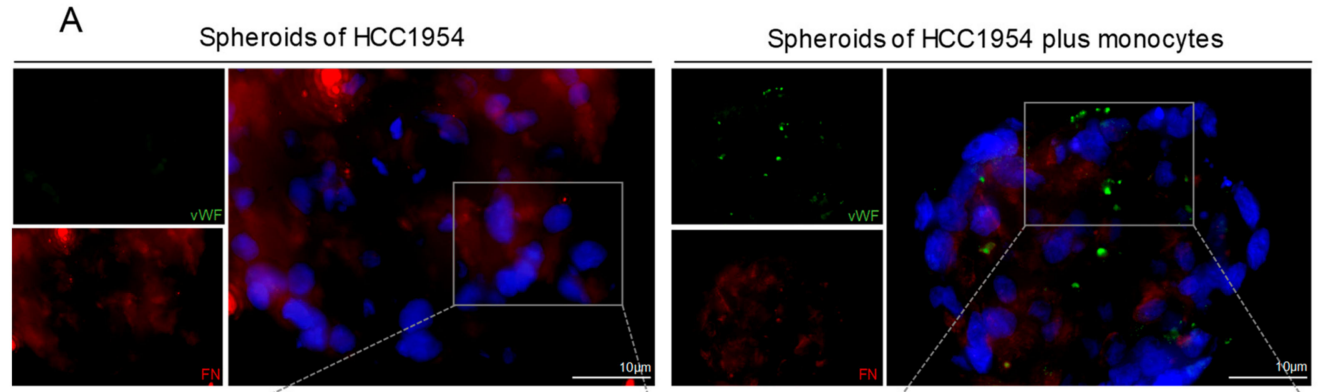

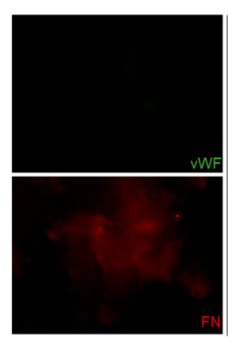

B

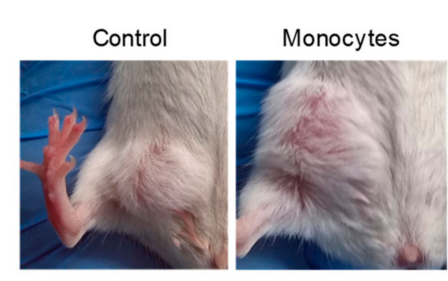

C
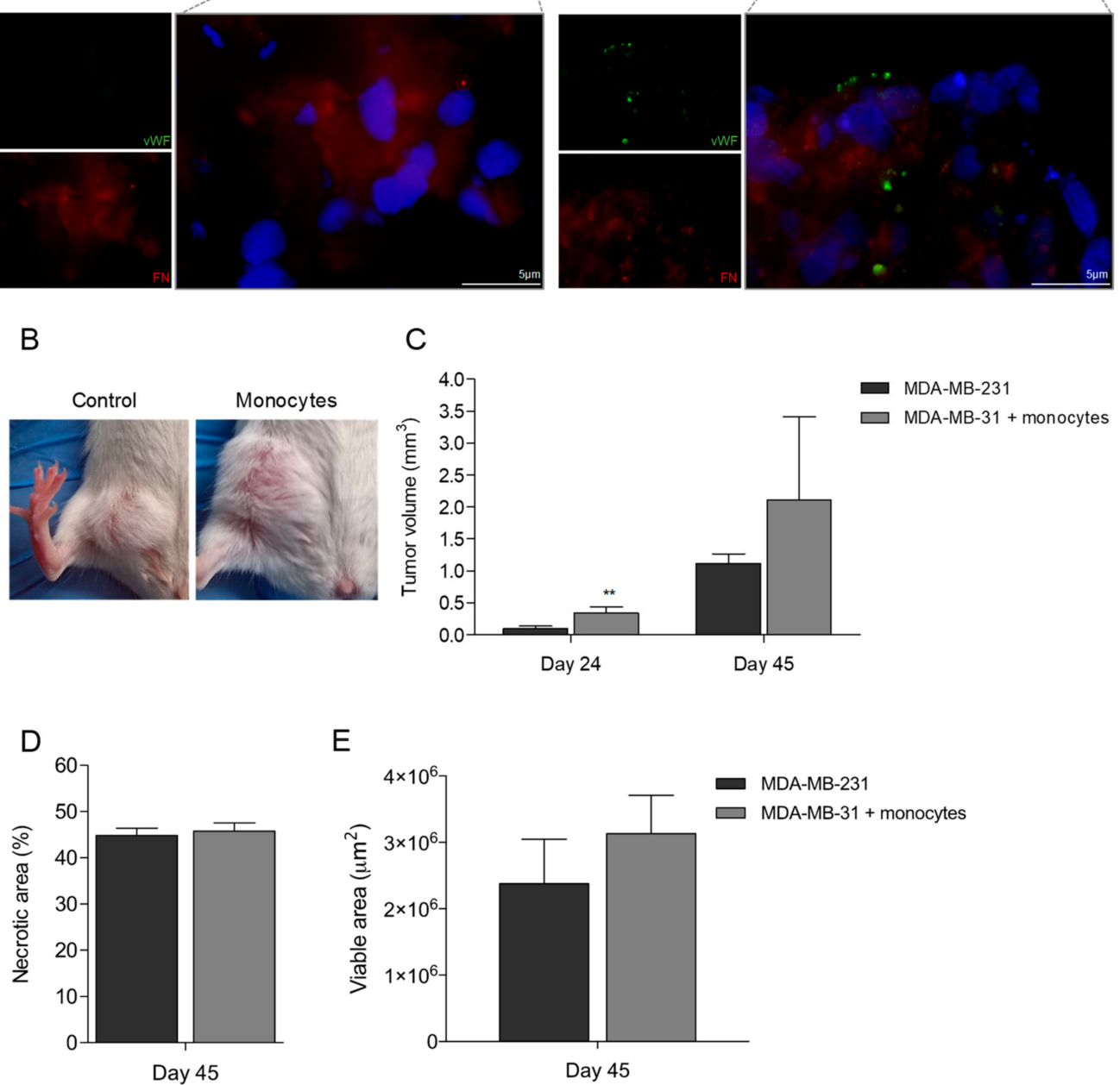

E

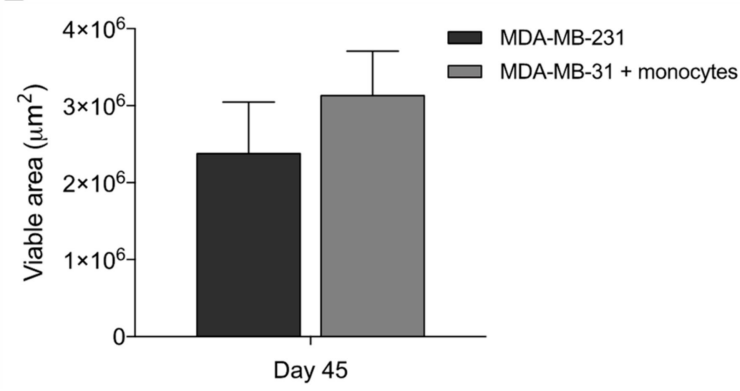

Figure 5. Cont. 
$\mathrm{F}$

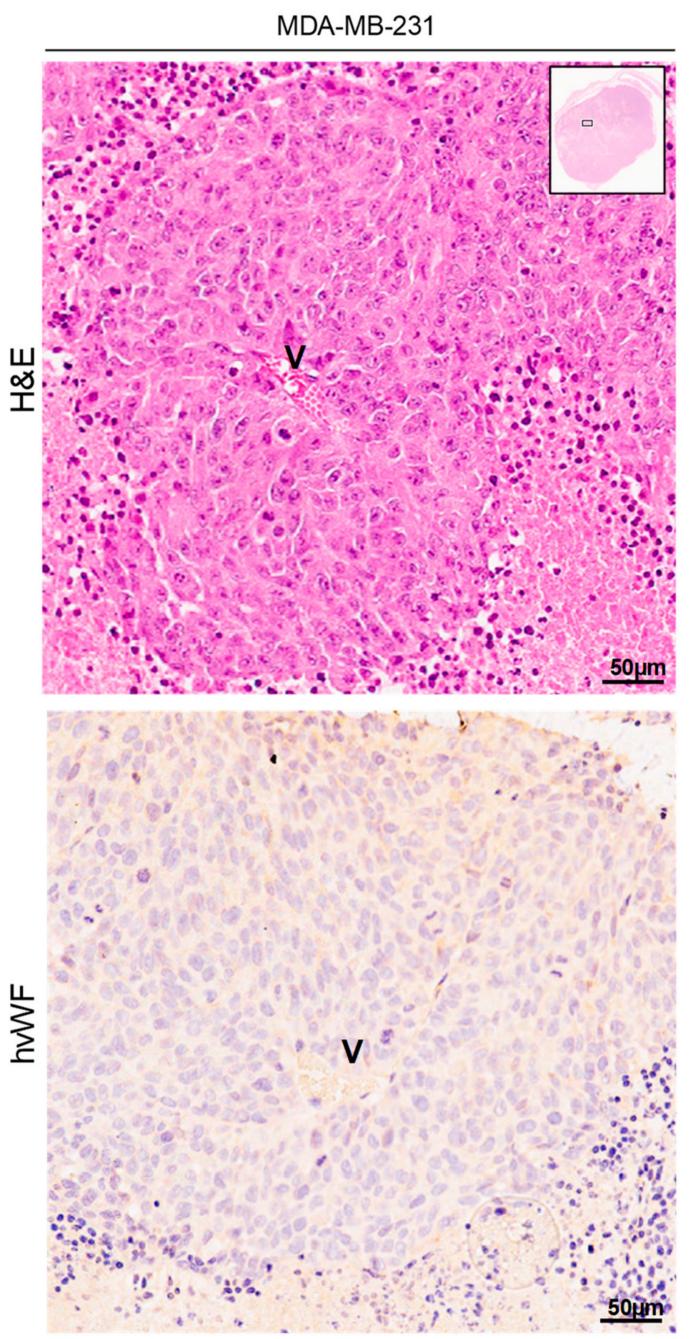

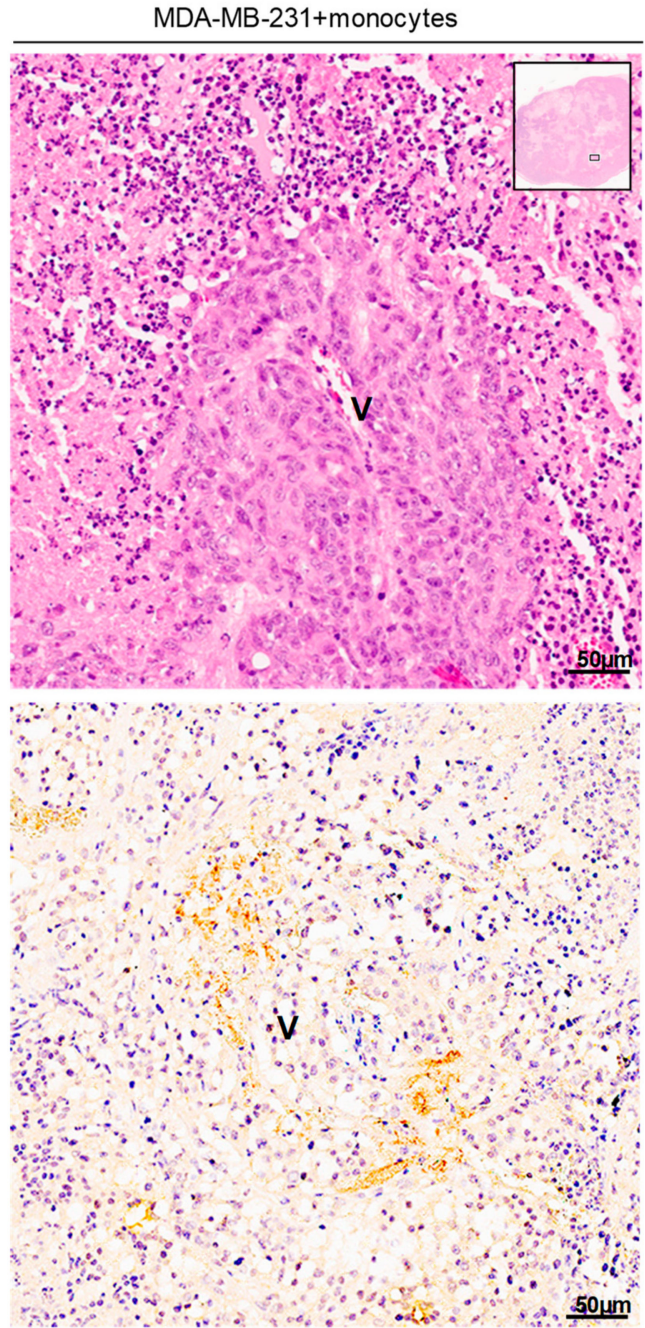

Figure 5. Tumors grown in the presence of monocytes have increased tumor volume and some vessels with human vWF (hvWF) staining. (A) 3D spheroids of HCC1954 in co-culture with monocytes stained for hvWF (green) and fibronectin (FN) (red) (bars $10 \mu \mathrm{m}$ ). DAPI (blue) stains nuclei, magnification 400x. (B) Representative imagens of tumors from mice with breast cancer cells (MDA-MB-231), without and with monocytes previously cultured under VEGF. (C) Tumor volume $\left(\mathrm{mm}^{3}\right) 24$ and 45 after inoculated mice with breast cancer cells (MDA-MB-231), without and with monocytes previously cultured under VEGF. (D) Quantification of tumor necrotic areas, 45 days after the inoculation of MDA-MB-231 with and without monocytes cultured in VEGF. (E) Quantification of tumor viable areas, 45 days after the inoculation of MDA-MB-231 with and without monocytes cultured in VEGF. (F) Immunohistochemistry (IHC) for hvWF (black arrow) in MDA-MB-231 tumors in the presence and absence of monocytes cultured in VEGF (bars $50 \mu \mathrm{m}$ ). Optical microscopy, nuclei are blue (hematoxylin). Blood vessels are signed with "V".

\section{Discussion}

In addition to their relevance in sprouting angiogenesis, EPC circulation, mobilization, and differentiation also play an essential role in the repair of injured vessels [4-6]. In recent years, the role of EPCs in the renewal of ECs integrity and function has gained attention from the scientific community, in particular, from the field of ischemia and cardiovascular disorders, opening new therapeutic perspectives for patient treatments [45-47]. So far, the lack of a precise panel of cell surface markers drives some heterogeneity in the methodologies used for EPCs identification. Furthermore, the very low representativeness of EPCs described so far creates a barrier for a better characterization of 
the molecular and biological processes underlying EPCs function, homing, and differentiation [48,49]. The exact definition of an EPC is still a matter of debate in the scientific community. We wonder if there are other cell subtypes that can also act as EPCs, which are more representative [50] in blood and are not, so far, addressed in studies regarding angiogenesis.

Reports in ischemia disclosed the involvement of bone marrow (BM)-derived mononuclear cells as contributors for angiogenesis, by being incorporated into neocapillaries and by allowing an increased vessel density [51-53]. A study from Nolan et al. [54] correlated early stages of tumor development with the differentiation potential of BM-derived EPCs and their incorporation into a subset of tumor neovessels. In a previous study using a panel of normal tissues and of tumors from vascular, epithelial, and embryonic origins, we showed that some cells on the vessel wall co-expressed CD14 (monocytic marker) and CD31 (EC marker) [22]. In accordance to this, another study showed that when macrophages are involved in vascular mimicry or interact with new forming blood vessels, they increase the expression of CD31 [55]. Thus, we hypothesized that monocytes could be involved in neovascularization, by acting as EPCs.

As a matter of fact, in vitro, we verified that freshly isolated monocytes, cultured in an endothelial specific medium (EBM2), exhibited a mixed expression profile of endothelial and macrophages markers (Figure 1A and Figure S1), but expressed very low levels of vWF a bona fide endothelial marker (Figure 1B). Therefore, monocytes gained vWF, together with CD146, expression upon endothelial differentiation (Figure 1E). However, when monocytes were cultured in stem and progenitor cell medium (CFU), they expressed low levels of all those markers (Figure 1A). Monocytes are recognized as a cell type that expresses VEGF receptors (VEGF-R) $[56,57]$ and our results show that, when cultured under the presence of VEFG, monocytes were able to acquire a spindle-cell-like morphology (Figure 1C), typical of ECs. This morphological remodeling was accompanied by an increased expression of CD31, vWF, and CD146 (EC marker) amongst other endothelial specific genes, concomitant with decreased expression of CD14 (monocytic/macrophagic marker) (Figure 1D-F). These in vitro results indicated that monocytes are close to a stem-cell like state, but, upon pro-endothelial/angiogenic stimulation, they differentiate into ECs.

Pathologies like cardiac ischemia or cancer have defective tissue perfusion, and excessive ROS levels and deregulated redox signaling account for re-vascularization of tissues and condition these disease outcomes [58-60]. In addition, ROS are essential for endothelium homeostasis and can stimulate or inhibit cell differentiation, depending on the cell type [29-32,61]. Considering the relevance of EPCs during vascular remodeling in pathologies with alterations in redox balance, we wonder if ROS would impact the monocytic-endothelial differentiation. Under exposure to $\mathrm{H}_{2} \mathrm{O}_{2}$, there was an increase in the expression of specific endothelial markers in monocytes, such as vWF, CD31, and CD146 (Figure 2A) and a decrease in the expression of the monocytic marker CD14 (Figure 2B). It is important to notice that monocytes, both maintained in EBM2 and in CFU media (prior $\mathrm{H}_{2} \mathrm{O}_{2}$ stimulation), were able to react to $\mathrm{H}_{2} \mathrm{O}_{2}$ by increasing the expression of $\mathrm{vWF}$ (Figure 2A); this highlights the relevance of ROS in inducing the differentiation of monocyte-derived ECs. The expression of some EC markers, such as CD31, is often observed in macrophagic cells in a cancer context and in vascular mimicry [55,62]. We opt to follow the expression of $\mathrm{vWF}$, since it is in fact a marker for ECs differentiation, as it is expressed and accumulated in Weibel-Palade bodies [63], which are endothelial storage granules. Accordingly, our images showing vWF expression in EC differentiating monocytes demonstrate a granular accumulation, typical of endothelial cells. Moreover, vWF is commonly used in other studies to identify cells undergoing endothelial differentiation [64-66].

Recently, in studies dedicated to cancer metabolism, our team showed that cysteine is beneficial for cells coping with ROS $[67,68]$. In monocytes, cysteine seemed to have the same role, by protecting cells against ROS effects. In this particular case, cysteine stopped the ROS-induced monocyte-ECs differentiation, as it prevented the expression of vWF and impaired the route of monocytes to EC-like differentiation (Figure 2C). 
EPCs are characterized by having active ALDH and a decrease in their expression and activity is correlated with a differentiation status of EPCs to ECs [36,37]. In a model of ischemia, decreased expression of ALDH was pointed out as a good strategy to induce rapid neovascularization and subsequent regeneration of ischemic tissues [69]. Our results showed that monocytes exposed to disulfiram, an irreversible inhibitor of ALDH, increased vWF expression in a pattern similar to that observed in monocytes exposed to $\mathrm{H}_{2} \mathrm{O}_{2}$ (Figure 2D,E), this way reinforcing the role of monocytes as EPCs. Thus, the decreased activity of ALDH prompts the monocyte-ECs differentiation process, in a similar manner to $\operatorname{ROS}\left(\mathrm{H}_{2} \mathrm{O}_{2}\right)$. The role of $\operatorname{ROS}\left(\mathrm{H}_{2} \mathrm{O}_{2}\right)$ as a stimulator of monocyte differentiation into ECs was reinforced by the observation that even when monocytes are shortly removed from CFU media, both disulfiram and $\mathrm{H}_{2} \mathrm{O}_{2}$ can induce the expression of vWF (Figure 2D). The evidence is compatible to the high plasticity and capacity of monocytes differentiating into ECs, without requiring a long-term ROS stimulus. The increased ROS levels during disease progression is a feature already assumed in cancer [70]. Therefore, our results reinforce the evidence that the metabolic remodeling of cancer cells contributes to a ROS enriched microenvironment, being a mean of orchestrating tumor neo-angiogenesis and favoring tumor growth and spread [71].

In a tumor microenvironment, stromal cells (e.g., fibroblasts, adipocytes, inflammatory, and smooth muscle cells) and cancer cells secret monocyte chemoattractant protein 1 (MCP-1) that leads to the recruitment of monocytes into the tumor [72-74]. Furthermore, the macrophage migration inhibitory factor (MIF), whose function as a regulator of inflammation remains controversial [75-77], seems to promote cancer progression by stimulating the recruitment of myeloid cells into the tumor [78-81], is also associated with increased angiogenesis [82,83]. Since MIF has been directly implicated in the regulation of endothelial differentiation [84], we believe that MIF as a tumor promoter proves again that monocytes-derived ECs can be a subpopulation of M2-TAMs, reaching the tumor to favor angiogenesis by also making part of the blood vessel structures. Interestingly, an oxidized isoform of MIF was identified as a prognostic biomarker and therapeutic target in inflammatory disease and cancer [85,86], showing again that the pro-oxidative tumor microenvironment is playing a role in angiogenesis.

The participation of monocytes in angiogenesis, via the production and release of pro-angiogenic factors, has been reported in inflammatory diseases [87-89]. However, our results suggest that monocytes, in addition to their role in the secretion of cytokines, pro-angiogenic factors (e.g., VEGF, VEGFC, and VEGFD, TNF $\alpha$, IL-8, and FGF-2) and ECM modifying proteins (e.g., MMP-9) [17,18], were also able to integrate new blood vessels by directly differentiating into ECs and incorporating the vessel structure (Figure 3). This phenomenon was observed macroscopically by a higher density of blood vessels in plugs inoculated with monocytes (Figure 3A) with an increased number of vessel-like structures (Figure 3B,C) expressing FN (Figure 3D,E), which indicates that those structures have a vessel basement membrane [90]. Moreover, using two different in vivo models, we unraveled human monocyte capacity to differentiate into ECs and incorporate blood vessels (Figure 3B,C). The strategy we used, by inoculating human male monocytes in plugs induced in female mice, undoubtedly proved that cells positive for hvWF were from human (Figure 3B,C) and male origin (Figure 3F). In addition, it was evident that not all vessel-like structures within the plug were from human origin (Figure 3D), since murine EPCs were also participating in the pro-angiogenic process [91] and might react in a more efficient way as they were reacting to endogenous murine signaling. A recent study, confronting autologous and heterologous EPCs transplantation models stated that in the autologous context, cells undergo homing and differentiation more efficiently [92].

The differentiation of monocytes into endothelial cells, expressing VWF, was also induced in murine aortas ex vivo (Figure 4), after endothelial dysfunction induced by LPS and LPA [41-43]. Again, the human origin of those cells incorporating injured aortas was assessed by using a human specific anti-vWF. Several studies have, shown that injured arteries are repaired by both the recruitment of new cells and the activation of the proliferation of endothelial cells [42,93-95]. In this experiment, monocytes worked as recruited EPCs, being able to incorporate an already structured but injured vessel. 
The efficacy of the use of anti-angiogenic therapies in cancer treatment have been disappointing so far. We believe this failure relies on the missing pieces to construct the entire angiogenic route. Considering that monocytes recruitment is a well-established step during carcinogenesis [96,97], we believe this recruitment favors tumor progression not only by differentiating into tumor associated macrophages (TAMs) [98-101], but also by acting as EPCs and differentiating into ECs. In a 3D co-culture system of breast cancer cells and monocytes, we detected hvWF positive cells that also expressed FN (Figure 5A). This suggested that, also in in vitro cancer 3D-models, monocytes can differentiate into ECs.

Once in the tumor and upon their activation, some monocytes can differentiate into macrophages that release cytokines and pro-angiogenic factors, whilst other monocytes can be targeted by this stimulation that will trigger their differentiation into ECs. This coordinated myeloid networking will favor tumor growth and disease progression. According to this, we observed, in vivo, that breast cancer cells inoculated in the presence of monocytes originated larger tumors in comparison to the control group (4- and 2-fold at day 24 and 45, respectively; Figure 5B,C). The necrotic area was similar in the two experimental groups (Figure 5D,E), showing that the viable area in tumors induced in the presence of monocytes is more extensive than the viable area in control tumors. This observation can roughly show that monocytes are acting as helpers for tumor development. Interestingly, in the viable regions of tumors inoculated with monocytes, but not in the control group, some ECs and cells close to the vessels were hvWF positive (Figure 5F). Therefore, in both the in vivo murine breast cancer model and the 3D in vitro model, we unraveled that monocytes have the potential to differentiate into ECs and be incorporated into the neo-vasculature, during tumor development.

Our study demonstrated that monocytes are in fact incorporated in blood vessels, cementing their underestimation as a relevant stanchion of vascular growth. Due to their $2-10 \%$ prevalence in peripheral blood [50] and comparing to the estimated percentage of EPCs proposed by other studies $[4-6,102,103]$, monocytes are putatively the most representative EPCs subgroup. Herein, we provided new evidence positioning a redox-dependence of monocytes under pro-angiogenic stimuli, which contributes for vascular growth (Figure 6). This new view on neoangiogenesis and ECs sources is worthy of further investigation, since a better understanding of monocytes biology as EPCs will propel novel paradigms for anti-angiogenic strategies and cancer therapy. 


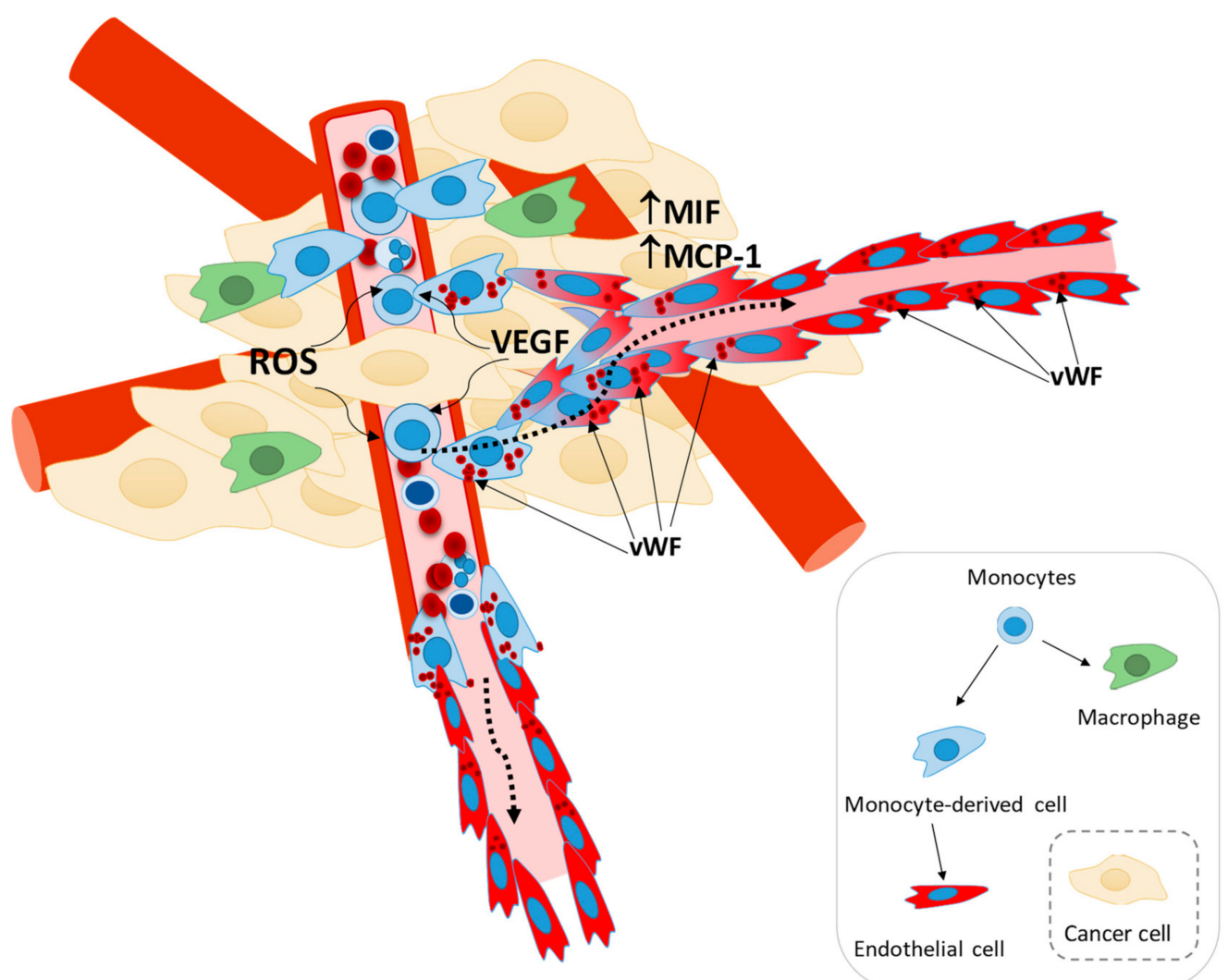

Figure 6. Monocytes recruitment into the tumor and endothelial differentiation. Our working model demonstrate that monocytes could act as EPCs and be incorporated into neo-vasculature. Monocytes are a cell subtype characterized as having high plasticity, and are able to differentiate into macrophages. We unravel that endothelial differentiation can also be an endpoint for monocytes. Monocyte-EC differentiation depends on a pro-angiogenic stimulus (e.g., VEGF) and oxidative stress (ROS). The acquisition of the expression of vWF (EC marker) is undoubtable evidence of this differentiation route, accounting for tumor vascularization and growth.

Supplementary Materials: The following are available online at http://www.mdpi.com/2073-4409/9/1/107/s1, Figure S1: Representative histograms of FACS analysis of CD14-monocytic marker, CD31, KDR, VE-Cadherin (VE-Cad)-EC markers and CD68, CD80, CD163 - macrophage markers in monocytes freshly isolated (Day0), monocytes maintained in CFU media and in Human umbilical vein ECs (HUVECs), Figure S2: Confirmation of the specificity of anti- human vWF (anti-hvWF; A0082, Dako-Agilent) in lung section from mouse and human origin.

Author Contributions: F.L.-C. planned and performed the assays and wrote the first draft of the paper; F.S., S.G.-F., C.M., N.L. and G.D. performed experiments and validated results; C.B. supervised the 3D models; A.M.A. supervised the project as an expert in hematology; S.A.P. supervised and discussed the project, and J.S. was responsible the scientific coordination and funding of the project. All the authors read, discussed and agreed with the final version of the manuscript. All authors have read and agreed to the published version of the manuscript.

Funding: The project was funded by IPOLFG, EPE, by iNOVA4Health (UID/Multi/04462/2019) a program financially supported by Fundação para a Ciência e Tecnologia/Ministério da Educação e Ciência, through national funds and co-funded by FEDER under the PT2020 Partnership Agreement and by Fundação para a Ciência e Tecnologia (PhD student fellowship: PD/BD/128337/2017).

Acknowledgments: The authors thank to Serviço de Imuno-Hemoterapia from Instituto Português de Oncologia de Lisboa Francisco Gentil (IPOLFG) for providing buffy coats from healthy donors and to Duarte Barral and Cristina Casalou from Membrane traffic in infection and disease at CEDOC|NMS-UNL for helping us to access the animal facility in NMS. We thank Otília Vieira from CEDOC|NMS-UNL and Edgar Gomes from Instituto de Medicina Molecular da Universidade de Lisboa (IMM-UL) for giving us LPS and LPA.

Conflicts of Interest: The authors disclose any conflict of interest. 


\section{References}

1. Yadav, L.; Puri, N.; Rastogi, V.; Satpute, P.; Sharma, V. Tumour angiogenesis and angiogenic inhibitors: A review. J. Clin. Diagn. Res. 2015, 9, XE01-XE05. [CrossRef] [PubMed]

2. Marmé, D. Tumor Angiogenesis: A Key Target for Cancer Therapy. Oncol. Res. Treat. 2018, 41, 164. [CrossRef] [PubMed]

3. Vasudev, N.S.; Reynolds, A.R. Anti-angiogenic therapy for cancer: Current progress, unresolved questions and future directions. Angiogenesis 2014, 17, 471-494. [CrossRef] [PubMed]

4. Yuan, J.; Yang, J.; Sun, S.; Zhang, R.; Xu, Y. Endothelial Progenitor Cells' Classification and Application in Neurological Diseases. Tissue Eng. Regen. Med. 2017, 14, 327-332. [CrossRef] [PubMed]

5. Yoder, M.C. Human endothelial progenitor cells. Cold Spring Harb. Perspect. Med. 2012, 2, a006692. [CrossRef] [PubMed]

6. Richardson, M.R.; Yoder, M.C. Endothelial progenitor cells: Quo Vadis? J. Mol. Cell. Cardiol. 2011, 50, 266-272. [CrossRef] [PubMed]

7. Del Papa, N.; Quirici, N.; Soligo, D.; Scavullo, C.; Cortiana, M.; Borsotti, C.; Maglione, W.; Comina, D.P.; Vitali, C.; Fraticelli, P.; et al. Bone marrow endothelial progenitors are defective in systemic sclerosis. Arthritis Rheum. 2006, 54, 2605-2615. [CrossRef]

8. Allanore, Y.; Batteux, F.; Avouac, J.; Assous, N.; Weill, B.; Kahan, A. Levels of circulating endothelial progenitor cells in systemic sclerosis. Clin. Exp. Rheumatol. 2007, 25, 60-66.

9. Avouac, J.; Juin, F.; Wipff, J.; Couraud, P.O.; Chiocchia, G.; Kahan, A.; Boileau, C.; Uzan, G.; Allanore, Y. Circulating endothelial progenitor cells in systemic sclerosis: Association with disease severity. Ann. Rheum. Dis. 2008, 67, 1455-1460. [CrossRef]

10. Nevskaya, T.; Bykovskaia, S.; Lyssuk, E.; Shakhov, I.; Zaprjagaeva, M.; Mach, E.; Ananieva, L.; Guseva, N.; Nassonov, E. Circulating endothelial progenitor cells in systemic sclerosis: Relation to impaired angiogenesis and cardiovascular manifestations. Clin. Exp. Rheumatol. 2008, 26, 21-29.

11. Plein, A.; Fantin, A.; Denti, L.; Pollard, J.W.; Ruhrberg, C. Erythro-myeloid progenitors contribute endothelial cells to blood vessels. Nature 2018, 562, 223-228. [CrossRef] [PubMed]

12. Urbich, C.; Heeschen, C.; Aicher, A.; Dernbach, E.; Zeiher, A.M.; Dimmeler, S. Relevance of Monocytic Features for Neovascularization Capacity of Circulating Endothelial Progenitor Cells. Circulation 2003, 108, 2511-2516. [CrossRef] [PubMed]

13. Nucera, S.; Biziato, D.; de Palma, M. The interplay between macrophages and angiogenesis in development, tissue injury and regeneration. Int. J. Dev. Biol. 2011, 55, 495-503. [CrossRef] [PubMed]

14. Lewis, C.E.; De Palma, M.; Naldini, L. Tie2-expressing monocytes and tumor angiogenesis: Regulation by hypoxia and angiopoietin-2. Cancer Res. 2007, 67, 8429-8432. [CrossRef] [PubMed]

15. Mazzieri, R.; Pucci, F.; Moi, D.; Zonari, E.; Ranghetti, A.; Berti, A.; Politi, L.S.; Gentner, B.; Brown, J.L.; Naldini, L.; et al. Targeting the ANG2/TIE2 Axis Inhibits Tumor Growth and Metastasis by Impairing Angiogenesis and Disabling Rebounds of Proangiogenic Myeloid Cells. Cancer Cell 2011, 19, 512-526. [CrossRef] [PubMed]

16. Willenborg, S.; Lucas, T.; Van Loo, G.; Knipper, J.A.; Krieg, T.; Haase, I.; Brachvogel, B.; Hammerschmidt, M.; Nagy, A.; Ferrara, N.; et al. CCR2 recruits an inflammatory macrophage subpopulation critical for angiogenesis in tissue repair. Blood 2012, 120, 613-625. [CrossRef] [PubMed]

17. Zumsteg, A.; Christofori, G. Corrupt policemen: Inflammatory cells promote tumor angiogenesis. Curr. Opin. Oncol. 2009, 21, 60-70. [CrossRef]

18. Deryugina, E.I.; Quigley, J.P. Tumor angiogenesis: MMP-mediated induction of intravasation-and metastasis-sustaining neovasculature. Matrix Biol. 2015, 44, 94-112. [CrossRef]

19. Schmeisser, A.; Garlichs, C.D.; Zhang, H.; Eskafi, S.; Graffy, C.; Ludwig, J.; Strasser, R.H.; Daniel, W.G. Monocytes coexpress endothelial and macrophagocytic lineage markers and form cord-like structures in Matrigel ${ }^{\circledR}$ under angiogenic conditions. Cardiovasc. Res. 2001, 49, 671-680. [CrossRef]

20. Yoder, M.C.; Mead, L.E.; Prater, D.; Krier, T.R.; Mroueh, K.N.; Li, F.; Krasich, R.; Temm, C.J.; Prchal, J.T.; Ingram, D.A. Redefining endothelial progenitor cells via clonal analysis and hematopoietic stem/progenitor cell principals. Blood 2007, 109, 1801-1809. [CrossRef]

21. Fadini, G.P.; Losordo, D.; Dimmeler, S. Critical reevaluation of endothelial progenitor cell phenotypes for therapeutic and diagnostic use. Circ. Res. 2012, 110, 624-637. [CrossRef] [PubMed] 
22. Domingues, G.; Fernandes, S.; Salgado, D.; Nunes, S.; Pereira, S.; Coelho, F.; Silva, F.; Félix, A.; Serpa, J. Monocytes/Macrophages in Cancer, from Tumor Aggressors to Vascular Components-A new Insight for Anti-Angiogenic Therapy. In Proceedings of the EACR-AACR-SIC Special Conference on Anticancer Drug Action and Drug Resistance from Cancer Biology to the Clinic, Florence, Italy, 20-23 June 2015; pp. 98-99.

23. Cai, H. Hydrogen peroxide regulation of endothelial function: Origins, mechanisms, and consequences. Cardiovasc. Res. 2005, 68, 26-36. [CrossRef] [PubMed]

24. Bretón-Romero, R.; Lamas, S. Hydrogen peroxide signaling in vascular endothelial cells. Redox Biol. 2014, 2, 529-534. [CrossRef] [PubMed]

25. Coyle, C.H.; Kader, K.N. Mechanisms of $\mathrm{H}_{2} \mathrm{O}_{2}$-induced oxidative stress in endothelial cells exposed to physiologic shear stress. ASAIO J. 2007, 53, 17-22. [CrossRef] [PubMed]

26. Satoh, K.; Godo, S.; Saito, H.; Enkhjargal, B.; Shimokawa, H. Dual roles of vascular-derived reactive oxygen species-With a special reference to hydrogen peroxide and cyclophilin A-. J. Mol. Cell. Cardiol. 2014, 73, 50-56. [CrossRef]

27. Park, W.H. The effects of exogenous $\mathrm{H}_{2} \mathrm{O}_{2}$ on cell death, reactive oxygen species and glutathione levels in calf pulmonary artery and human umbilical vein endothelial cells. Int. J. Mol. Med. 2013, 31, 471-476. [CrossRef]

28. Chen, Q.; Wang, Q.; Zhu, J.; Xiao, Q.; Zhang, L. Reactive oxygen species: Key regulators in vascular health and diseases. Br. J. Pharmacol. 2018, 175, 1279-1292. [CrossRef]

29. Xiao, Y.; Li, X.; Cui, Y.; Zhang, J.; Liu, L.; Xie, X.; Hao, H.; He, G.; Kander, M.C.; Chen, M.; et al. Hydrogen peroxide inhibits proliferation and endothelial differentiation of bone marrow stem cells partially via reactive oxygen species generation. Life Sci. 2014, 112, 33-40. [CrossRef]

30. Chaudhari, P.; Ye, Z.; Jang, Y.Y. Roles of Reactive Oxygen Species in the Fate of Stem Cells. Antioxid. Redox Signal. 2014, 20, 1881-1890. [CrossRef]

31. Wang, F.; Wang, Y.Q.; Cao, Q.; Zhang, J.J.; Huang, L.Y.; Sang, T.T.; Liu, F.; Chen, S.Y. Hydrogen peroxide induced impairment of endothelial progenitor cell viability is mediated through a FoxO3a dependant mechanism. Microvasc. Res. 2013, 90, 48-54. [CrossRef]

32. Ji, A.R.; Ku, S.Y.; Cho, M.S.; Kim, Y.Y.; Kim, Y.J.; Oh, S.K.; Kim, S.H.; Moon, S.Y.; Choi, Y.M. Reactive oxygen species enhance differentiation of human embryonic stem cells into mesendodermal lineage. Exp. Mol. Med. 2010, 42, 175-186. [CrossRef] [PubMed]

33. Archidiacono, N.; Antonacci, R.; Marzella, R.; Finelli, P.; Lonoce, A.; Rocchi, M. Comparative mapping of human alphoid sequences in great apes using fluorescence in situ hybridization. Genomics 1995, 25, 477-484. [CrossRef]

34. Cooke, H.J.; Schmidtke, J.; Gosden, J.R. Characterisation of a human Y chromosome repeated sequence and related sequences in higher primates. Chromosoma 1982, 87, 491-502. [CrossRef] [PubMed]

35. Martins, C.; Fonseca, I.; Roque, L.; Pereira, T.; Ribeiro, C.; Bullerdiek, J.; Soares, J. PLAG1 gene alterations in salivary gland pleomorphic adenoma and carcinoma ex-pleomorphic adenoma: A combined study using chromosome banding, in situ hybridization and immunocytochemistry. Mod. Pathol. 2005, 18, 1048-1055. [CrossRef] [PubMed]

36. Vassalli, G. Aldehyde Dehydrogenases: Not Just Markers, but Functional Regulators of Stem Cells. Stem Cells Int. 2019, 2019, 3904645. [CrossRef] [PubMed]

37. Blix, E.S.; Kildal, A.B.; Bertelsen, E.; Waage, A.; Myklebust, J.H.; Kolstad, A.; Husebekk, A. Content of endothelial progenitor cells in autologous stem cellgrafts predict survival after transplantation for multiplemyeloma. Biol. Blood Marrow Transplant. 2015, 21, 840-847. [CrossRef]

38. Koppaka, V.; Thompson, D.C.; Chen, Y.; Ellermann, M.; Nicolaou, K.C.; Juvonen, R.O.; Petersen, D.; Deitrich, R.A.; Hurley, T.D.; Vasiliou, V. Aldehyde Dehydrogenase Inhibitors: A Comprehensive Review of the Pharmacology, Mechanism of Action, Substrate Specificity, and Clinical Application. Pharmacol. Rev. 2012, 64, 520-539. [CrossRef]

39. Kolachala, V.L.; Bajaj, R.; Wang, L.; Yan, Y.; Ritzenthaler, J.D.; Gewirtz, A.T.; Roman, J.; Merlin, D.; Sitaraman, S.V. Epithelial-derived fibronectin expression, signaling, and function in intestinal inflammation. J. Biol. Chem. 2007, 282, 32965-32973. [CrossRef]

40. Hielscher, A.; Ellis, K.; Qiu, C.; Porterfield, J.; Gerecht, S. Fibronectin deposition participates in extracellular matrix assembly and vascular morphogenesis. PLOS ONE 2016, 11, e0147600. [CrossRef] 
41. Cai, J.; Wei, J.; Li, S.; Suber, T.; Zhao, J. AM966, an Antagonist of Lysophosphatidic Acid Receptor 1, Increases Lung Microvascular Endothelial Permeability through Activation of Rho Signaling Pathway and Phosphorylation of VE-Cadherin. Mediat. Inflamm. 2017, 2017, 6893560. [CrossRef]

42. Nogueras, S.; Merino, A.; Ojeda, R.; Carracedo, J.; Rodriguez, M.; Martin-Malo, A.; Ramírez, R.; Aljama, P. Coupling of endothelial injury and repair: An analysis using an in vivo experimental model. Am. J. Physiol 2008, 294, H708-H713. [CrossRef]

43. Teo, S.T.; Yung, Y.C.; Herr, D.R.; Chun, J. Lysophosphatidic acid in vascular development and disease. IUBMB Life 2009, 61, 791-799. [CrossRef] [PubMed]

44. Rebelo, S.P.; Pinto, C.; Martins, T.R.; Harrer, N.; Estrada, M.F.; Loza-Alvarez, P.; Cabeçadas, J.; Alves, P.M.; Gualda, E.J.; Sommergruber, W.; et al. 3D-3-culture: A tool to unveil macrophage plasticity in the tumour microenvironment. Biomaterials 2018, 163, 185-197. [CrossRef] [PubMed]

45. Luo, F.; Wu, P.; Chen, J.; Guo, Y.; Wang, J.; Li, X.; Fang, Z. ANGPTL3 possibly promotes cardiac angiogenesis through improving proangiogenic ability of endothelial progenitor cells after myocardial infarction. Lipids Health Dis. 2018, 17, 184. [CrossRef] [PubMed]

46. Montenegro, F.S.; Correia, M.; Muccillo, F.; Souza Silva, C.G.E.; De Lorenzo, A. Associations between endothelial progenitor cells, clinical characteristics and coronary restenosis in patients undergoing percutaneous coronary artery intervention. BMC Res. Notes 2018, 11, 278. [CrossRef]

47. Haider, K.H.; Aziz, S.; Al-Reshidi, M.A. Endothelial progenitor cells for cellular angiogenesis and repair: Lessons learned from experimental animal models. Regen. Med. 2017, 12, 969-982. [CrossRef]

48. Pelosi, E.; Castelli, G.; Testa, U. Endothelial progenitors. Blood Cells Mol. Dis. 2014, 52, 186-194. [CrossRef]

49. Basile, D.P.; Yoder, M.C. Circulating and Tissue Resident Endothelial Progenitor Cells. J. Cell. Physiol 2014, 229, 10-16. [CrossRef]

50. Curry, C.V. Differential Blood Count: Reference Range, Interpretation, Collection and Panels; Medscape: Boston, MA, USA, 2016.

51. Kamihata, H.; Matsubara, H.; Nishiue, T.; Fujiyama, S.; Tsutsumi, Y.; Ozono, R.; Masaki, H.; Mori, Y.; Iba, O.; Tateishi, E.; et al. Implantation of bone marrow mononuclear cells into ischemic myocardium enhances collateral perfusion and regional function via side supply of angioblasts, angiogenic ligands, and cytokines. Circulation 2001, 104, 1046-1052. [CrossRef]

52. Karcher, J.R.; Greene, A.S. Bone marrow mononuclear cell angiogenic competency is suppressed by a high-salt diet. Am. J. Physiol. Cell Physiol. 2013, 306, C123-C131. [CrossRef]

53. Van Huyen, J.P.D.; Smadja, D.M.; Bruneval, P.; Gaussem, P.; Dal-Cortivo, L.; Julia, P.; Fiessinger, J.N.; Cavazzana-Calvo, M.; Aiach, M.; Emmerich, J. Bone marrow-derived mononuclear cell therapy induces distal angiogenesis after local injection in critical leg ischemia. Mod. Pathol. 2008, 21, 837-846. [CrossRef] [PubMed]

54. Nolan, D.J.; Ciarrocchi, A.; Mellick, A.S.; Jaggi, J.S.; Bambino, K.; Gupta, S.; Heikamp, E.; McDevitt, M.R.; Scheinberg, D.A.; Benezra, R.; et al. Bone marrow-derived endothelial progenitor cells are a major determinant of nascent tumor neovascularization. Genes Dev. 2007, 21, 1546-1558. [CrossRef] [PubMed]

55. Barnett, F.H.; Rosenfeld, M.; Wood, M.; Kiosses, W.B.; Usui, Y.; Marchetti, V.; Aguilar, E.; Friedlander, M. Macrophages form functional vascular mimicry channels in vivo. Sci. Rep. 2016, 11, 36659. [CrossRef] [PubMed]

56. Cuadrado, M.J.; Buendía, P.; Velasco, F.; Aguirre, M.A.; Barbarroja, N.; Torres, L.A.; Khamashta, M.; López-Pedrera, C. Vascular endothelial growth factor expression in monocytes from patients with primary antiphospholipid syndrome. J. Thromb. Haemost. 2006, 4, 2461-2469. [CrossRef]

57. Barleon, B.; Sozzani, S.; Zhou, D.; Weich, H.A.; Mantovani, A.; Marmé, D. Migration of human monocytes in response to vascular endothelial growth factor (VEGF) is mediated via the VEGF receptor flt-1. Blood 1996, 87, 3336-3343. [CrossRef]

58. Zhou, T.; Prather, E.R.; Garrison, D.E.; Zuo, L. Interplay between ROS and antioxidants during ischemia-reperfusion injuries in cardiac and skeletal muscle. Int. J. Mol. Sci. 2018, 19, 417. [CrossRef]

59. Gu, H.; Huang, T.; Shen, Y.; Liu, Y.; Zhou, F.; Jin, Y.; Sattar, H.; Wei, Y. Reactive Oxygen Species-Mediated Tumor Microenvironment Transformation: The Mechanism of Radioresistant Gastric Cancer. Oxid. Med. Cell. Longev. 2018, 2018, 5801209. [CrossRef]

60. Kumari, S.; Badana, A.K.; Murali Mohan, G.; Shailender, G.; Malla, R.R. Reactive Oxygen Species: A Key Constituent in Cancer Survival. Biomark. Insights 2018, 13, 1177271918755391. [CrossRef] 
61. Pashkovskaia, N.; Gey, U.; Rödel, G. Mitochondrial ROS direct the differentiation of murine pluripotent P19 cells. Stem Cell Res. 2018, 30, 180-191. [CrossRef]

62. McKenney, J.K.; Weiss, S.W.; Folpe, A.L. CD31 expression in intratumoral macrophages: A potential diagnostic pitfall. Am. J. Surg. Pathol. 2001, 25, 1167-1173. [CrossRef]

63. Castaman, G.; Giacomelli, S.H.; Jacobi, P.M.; Obser, T.; Budde, U.; Rodeghiero, F.; Schneppenheim, R.; Haberichter, S.L. Reduced von Willebrand factor secretion is associated with loss of Weibel-Palade body formation. J. Thromb. Haemost. 2012, 10, 951-958. [CrossRef] [PubMed]

64. Eggermann, J.; Kliche, S.; Jarmy, G.; Hoffmann, K.; Mayr-Beyrle, U.; Debatin, K.M.; Waltenberger, J.; Beltinger, C. Endothelial progenitor cell culture and differentiation in vitro: A methodological comparison using human umbilical cord blood. Cardiovasc. Res. 2003, 58, 478-486. [CrossRef]

65. Chu, H.; Sun, Y.; Gao, Y.; Guan, X.; Yan, H.; Cui, X.; Zhang, X.; Li, X.; Li, H.; Cheng, M. Function of Krüppel like factor 2 in the shear stress induced cell differentiation of endothelial progenitor cells to endothelial cells. Mol. Med. Rep. 2019, 19, 1739-1746. [PubMed]

66. Ge, Q.; Zhang, H.; Hou, J.; Wan, L.; Cheng, W.; Wang, X.; Dong, D.; Chen, C.; Xia, J.; Guo, J.; et al. VEGF secreted by Mesenchymal stem cells mediates the differentiation of endothelial progenitor cells into endothelial cells via paracrine mechanisms. Mol. Med. Rep. 2018, 17, 1667-1675. [CrossRef] [PubMed]

67. Nunes, S.C.; Lopes-Coelho, F.; Gouveia-Fernandes, S.; Ramos, C.; Pereira, S.A.; Serpa, J. Cysteine boosters the evolutionary adaptation to $\mathrm{CoCl} 2$ mimicked hypoxia conditions, favouring carboplatin resistance in ovarian cancer. BMC Evol. Biol. 2018, 18, 97. [CrossRef] [PubMed]

68. Nunes, S.C.; Ramos, C.; Lopes-Coelho, F.; Sequeira, C.O.; Silva, F.; Gouveia-Fernandes, S.; Rodrigues, A.; Guimarães, A.; Silveira, M.; Abreu, S.; et al. Cysteine allows ovarian cancer cells to adapt to hypoxia and to escape from carboplatin cytotoxicity. Sci. Rep. 2018, 8, 9513. [CrossRef]

69. Nagano, M.; Yamashita, T.; Hamada, H.; Ohneda, K.; Kimura, K.I.; Nakagawa, T.; Shibuya, M.; Yoshikawa, H.; Ohneda, O. Identification of functional endothelial progenitor cells suitable for the treatment of ischemic tissue using human umbilical cord blood. Blood 2007, 110, 151-160. [CrossRef]

70. Weinberg, F.; Ramnath, N.; Nagrath, D. Reactive Oxygen Species in the Tumor Microenvironment: An Overview. Cancers 2019, 11, 1191. [CrossRef]

71. Kim, Y.W.; Byzova, T.V. Oxidative stress in angiogenesis and vascular disease. Blood 2014, 123, 625-631. [CrossRef]

72. Yoshimura, T. The chemokine MCP-1 (CCL2) in the host interaction with cancer: A foe or ally? Cell. Mol. Immunol. 2018, 15, 335-345. [CrossRef]

73. Deshmane, S.L.; Kremlev, S.; Amini, S.; Sawaya, B.E. Monocyte Chemoattractant Protein-1 (MCP-1): An Overview. J. Interface Cytokine Res. 2009, 29, 313-326. [CrossRef] [PubMed]

74. Lim, S.Y.; Yuzhalin, A.E.; Gordon-Weeks, A.N.; Muschel, R.J. Targeting the CCL2-CCR2 signaling axis in cancer metastasis. Oncotarget 2016, 7, 28697-28710. [CrossRef] [PubMed]

75. Kasama, T.; Ohtsuka, K.; Sato, M.; Takahashi, R.; Wakabayashi, K.; Kobayashi, K. Macrophage Migration Inhibitory Factor: A Multifunctional Cytokine in Rheumatic Diseases. Arthritis 2010, 20, 751-762. [CrossRef] [PubMed]

76. Chen, L.; Zhou, X.; Fan, L.X.; Yao, Y.; Swenson-Fields, K.I.; Gadjeva, M.; Wallace, D.P.; Peters, D.J.M.; Yu, A.; Grantham, J.J.; et al. Macrophage migration inhibitory factor promotes cyst growth in polycystic kidney disease. J. Clin. Investig. 2015, 125, 2399-2412. [CrossRef]

77. Nishihira, J. Macrophage migration inhibitory factor (MIF): Its essential role in the immune system and cell growth. J. Interface Cytokine Res. 2000, 20, 751-762. [CrossRef]

78. Simpson, K.D.; Templeton, D.J.; Cross, J.V. Macrophage Migration Inhibitory Factor Promotes Tumor Growth and Metastasis by Inducing Myeloid-Derived Suppressor Cells in the Tumor Microenvironment. J. Immunol. 2012, 189, 5533-5540. [CrossRef]

79. Wang, S.S.; Cen, X.; Liang, X.H.; Tang, Y.L. Macrophage migration inhibitory factor: A potential driver and biomarker for head and neck squamous cell carcinoma. Oncotarget 2017, 8, 10650-10661. [CrossRef]

80. Zhang, H.; Ye, Y.L.; Li, M.X.; Ye, S.B.; Huang, W.R.; Cai, T.T.; He, J.; Peng, J.Y.; Duan, T.H.; Cui, J.; et al. CXCL2/MIF-CXCR2 signaling promotes the recruitment of myeloid-derived suppressor cells and is correlated with prognosis in bladder cancer. Oncogene 2017, 36, 2095-2104. [CrossRef]

81. He, L.J.; Xie, D.; Hu, P.J.; Liao, Y.J.; Deng, H.X.; Kung, H.F.; Zhu, S.L. Macrophage migration inhibitory factor as a potential prognostic factor in gastric cancer. World J. Gastroenterol. 2015, 21, 9916-9926. [CrossRef] 
82. Mangano, K.; Mazzon, E.; Basile, M.S.; Marco, R.D.; Bramanti, P.; Mammana, S.; Petralia, M.C.; Fagone, P.; Nicoletti, F. Pathogenic role for macrophage migration inhibitory factor in glioblastoma and its targeting with specific inhibitors as novel tailored therapeutic approach. Oncotarget 2018, 9, 17951-17970. [CrossRef]

83. Girard, E.; Strathdee, C.; Trueblood, E.; Quéva, C. Macrophage migration inhibitory factor produced by the tumour stroma but not by tumour cells regulates angiogenesis in the B16-F10 melanoma model. Br. J. Cancer 2012, 107, 1498-1505. [CrossRef] [PubMed]

84. Cui, J.; Zhang, F.; Wang, Y.; Liu, J.; Ming, X.; Hou, J.; Lv, B.; Fang, S.; Yu, B. Macrophage migration inhibitory factor promotes cardiac stem cell proliferation and endothelial differentiation through the activation of the PI3K/Akt/mTOR and AMPK pathways. Int. J. Mol. Med. 2016, 37, 1299-1309. [CrossRef] [PubMed]

85. Schinagl, A.; Thiele, M.; Douillard, P.; Völkel, D.; Kenner, L.; Kazemi, Z.; Freissmuth, M.; Scheiflinger, F.; Kerschbaumer, R.J. Oxidized macrophage migration inhibitory factor is a potential new tissue marker and drug target in cancer. Oncotarget 2016, 7, 73486. [CrossRef] [PubMed]

86. Mahalingam, D.; Patel, M.; Sachdev, J.; Hart, L.; Halama, N.; Ramanathan, R.; Sarantopoulos, J.; Liu, X.; Yazji, S.; Jäger, D.; et al. Safety and efficacy analysis of imalumab, an anti-oxidized macrophage migration inhibitory factor (oxMIF) antibody, alone or in combination with 5-fluorouracil/leucovorin (5-FU/LV) or panitumumab, in patients with metastatic colorectal cancer (mCRC). Ann. Oncol. 2016, 27, ii105. [CrossRef]

87. Cursiefen, C.; Chen, L.; Borges, L.P.; Jackson, D.; Cao, J.; Radziejewski, C.; D’Amore, P.A.; Dana, M.R.; Wiegand, S.J.; Streilein, J.W. VEGF-A stimulates lymphangiogenesis and hemangiogenesis in inflammatory neovascularization via macrophage recruitment. J. Clin. Investig. 2004, 113, 1040-1050. [CrossRef] [PubMed]

88. Eubank, T.D.; Galloway, M.; Montague, C.M.; Waldman, W.J.; Marsh, C.B. M-CSF Induces Vascular Endothelial Growth Factor Production and Angiogenic Activity From Human Monocytes. J. Immunol. 2003, 171, 2637-2643. [CrossRef] [PubMed]

89. Clark, A.N.; Youkey, R.; Liu, X.; Jia, L.; Blatt, R.; Day, Y.J.; Sullivan, G.W.; Linden, J.; Tucker, A.L. A1 adenosine receptor activation promotes angiogenesis and release of VEGF from monocytes. Circ. Res. 2007, 171, 2637-2643.

90. Xu, J.; Shi, G.P. Vascular wall extracellular matrix proteins and vascular diseases. Biochim. Biophys. Acta 2014, 1842, 2106-2119. [CrossRef]

91. Malinda, K.M. In vivo Matrigel Migration and Angiogenesis Assay. In Methods in Molecular Biology; Springer: Clifton, NJ, USA, 2009; pp. 287-294.

92. Qin, M.; Guan, X.; Zhang, Y.; Shen, B.; Liu, F.; Zhang, Q.; Ma, Y.; Jiang, Y. Evaluation of ex vivo produced endothelial progenitor cells for autologous transplantation in primates. Stem Cell Res. Ther. 2018, 9, 14. [CrossRef]

93. Kong, J.; Wang, F.; Zhang, J.; Cui, Y.; Pan, L.; Zhang, W.; Wen, J.; Liu, P. Exosomes of endothelial progenitor cells inhibit neointima formation after carotid artery injury. J. Surg. Res. 2018, 232, 398-407. [CrossRef]

94. Zhao, W.N.; Xu, S.Q.; Liang, J.F.; Peng, L.; Liu, H.L.; Wang, Z.; Fang, Q.; Wang, M.; Yin, W.Q.; Zhang, W.J.; et al. Endothelial progenitor cells from human fetal aorta cure diabetic foot in a rat model. Metabolism 2016, 65, 1755-1767. [CrossRef] [PubMed]

95. Zhao, Y.Y.; Gao, X.P.; Zhao, Y.D.; Mirza, M.K.; Frey, R.S.; Kalinichenko, V.V.; Wang, I.C.; Costa, R.H.; Malik, A.B. Endothelial cell-restricted disruption of FoxM1 impairs endothelial repair following LPS-induced vascular injury. J. Clin. Investig. 2006, 116, 2333-2343. [CrossRef] [PubMed]

96. Karlmark, K.; Tacke, F.; Dunay, I. Monocytes in health and disease-Minireview. Eur. J. Microbiol. Immunol. 2012, 2, 97-102. [CrossRef] [PubMed]

97. Olingy, C.E.; Dinh, H.Q.; Hedrick, C.C. Monocyte heterogeneity and functions in cancer. J. Leukoc. Biol. 2019, 106, 309-322. [CrossRef]

98. Cortés, M.; Sanchez-Moral, L.; de Barrios, O.; Fernández-Aceñero, M.J.; Martínez-Campanario, M.; Esteve-Codina, A.; Darling, D.S.; Győrffy, B.; Lawrence, T.; Dean, D.C.; et al. Tumor-associated macrophages (TAMs) depend on ZEB1 for their cancer-promoting roles. EMBO J. 2017, 36, 3336-33355. [CrossRef] [PubMed]

99. Wei, C.; Yang, C.; Wang, S.; Shi, D.; Zhang, C.; Lin, X.; Liu, Q.; Dou, R.; Xiong, B. Crosstalk between cancer cells and tumor associated macrophages is required for mesenchymal circulating tumor cell-mediated colorectal cancer metastasis. Mol. Cancer 2019, 18, 64. [CrossRef]

100. Lopes-Coelho, F.; Gouveia-Fernandes, S.; Serpa, J. Metabolic cooperation between cancer and non-cancerous stromal cells is pivotal in cancer progression. Tumor Biol. 2018, 40, 1010428318756203. [CrossRef] 
101. Niu, Z.; Shi, Q.; Zhang, W.; Shu, Y.; Yang, N.; Chen, B.; Wang, Q.; Zhao, X.; Chen, J.; Cheng, N.; et al. Caspase-1 cleaves PPAR $\gamma$ for potentiating the pro-tumor action of TAMs. Nat. Commun. 2017, 8, 766. [CrossRef]

102. Tal, R.; Dong, D.; Shaikh, S.; Mamillapalli, R.; Taylor, H.S. Bone-marrow-derived endothelial progenitor cells contribute to vasculogenesis of pregnant mouse uterus. Biol. Reprod. 2019, 100, 1228-1237. [CrossRef]

103. Kaur, S.; Sehgal, R.; Shastry, S.M.; McCaughan, G.; McGuire, H.M.; St de Groth, B.F.; Sarin, S.; Trehanpati, N.; Seth, D. Circulating endothelial progenitor cells present an inflammatory phenotype and function in patients with alcoholic liver cirrhosis. Front. Physiol. 2018, 9, 556. [CrossRef]

(C) 2020 by the authors. Licensee MDPI, Basel, Switzerland. This article is an open access article distributed under the terms and conditions of the Creative Commons Attribution (CC BY) license (http://creativecommons.org/licenses/by/4.0/). 